\title{
Detection of the impact of predation by migratory shorebirds: an experimental test in the Fraser River estuary, British Columbia (Canada)
}

\author{
Mary A. Sewell* \\ Dept of Biological Sciences, Simon Fraser University, Burnaby, British Columbia, Canada V5A 1S6 \\ and
}

Environment Canada, Pacific Wildlife Research Centre, RR1 5421 Robertson Road, Delta, British Columbia, Canada V4K 3N2

\begin{abstract}
Exclosure experiments are commonly used in marine soft sediments to examine changes in invertebrate density caused by shorebird predation. However, many of these exclosure experiments do not incorporate the spatial variability of the invertebrate prey in their design and/or analysis. This paper uses a short-term exclosure experiment and random sampling (Before/After predation) to assess reductions in invertebrate densities by western sandpiper Calidris mauri on the Fraser River estuary, British Columbia, Canada. During the spring $>1$ million western sandpiper stop over at the Fraser River estuary on their northward migration to breeding grounds in Alaska. Exclosure experiments and Before/After sampling were conducted at 3 sites on the Fraser River estuary that differed in their sediment characteristics and in their use for feeding by western sandpiper. An examination of cage effects showed that there were no alterations to sediment composition caused by the exclosure cage. However, there were changes in invertebrate numbers in the exclosure cage irrespective of shorebird predation. In particular, mobile invertebrates, such as gastropods and crustaceans, migrated into or out of the exclosure cages during the experiment. Overall, there was little evidence for reduction in invertebrate numbers caused by western sandpiper predation. In the exclosure experiment a significant decline was observed in the phyllodocid polychaete Eteone spp., but at a site with little evidence of shorebird predation. Before/After sampling showed some declines in invertebrate numbers, but this could reflect patchiness in invertebrate distributions rather than the direct action of predation. The use of statistical desıgns for detecting environmental impacts (e.g. BACl) is suggested for future studies of shorebird predation as they allow for the spatial and temporal variability of the invertebrate prey to be considered concomitant with the impact of the shorebird predator. General problems of sampling with sediment cores, high sample variance, and the reduced power of experimental tests need to be considered in future research on the interactions of shorebird predators and their marine invertebrate prey.
\end{abstract}

KEY WORDS: Shorebird predation Western sandpiper Calidris mauri Soft sediments Exclosure experiment

\section{INTRODUCTION}

Exclosure experiments have been widely used to study the impact of predation by migratory shorebirds at both overwintering sites and stopover areas (reviewed by Baird et al. 1985, Piersma 1987, Székely \& Bamberger 1992, Ólafsson et al. 1994). However, con-

- Present address: Harbor Branch Oceanographic Institution, 5600 U.S. 1 North, Fort Pierce, Florida 34946, USA.

E-mail: sewell@hboi.edu sidering the a priori assumption that shorebirds remove a high proportion of the benthic productivity from intertidal areas (review of Baird et al. 1985: 6 to $44 \%$ of prey production), there are few exclosure studies that have detected a significant reduction in invertebrate numbers by shorebirds. Only 5 studies have shown statistical differences in invertebrate numbers inside and outside exclosure cages after the period of shorebird predation, and often for only a subset of invertebrate species, or at restricted study sites (Schneider 1978, Schneider \& Harrington 1981, Kent \& 
Day 1983, Quammen 1984, Mercier \& McNeil 1994). In contrast, numerous studies have shown no reduction in invertebrate numbers in areas exposed to shorebird predation (Goss-Custard 1977, Reise 1978, Duffy et al. 1981, Botton 1984, Raffaelli \& Milne 1987, Wilson 1989, 1991a, 1994b, Kalejta 1993).

For a clear demonstration of the importance of shorebird predation on infaunal marine invertebrates, experimenters need to consider the importance of experimental design (Hall et al. 1990b), cage effects (Virnstein 1978, Peterson 1979, Hulberg \& Oliver 1980), the spatial layout of the treatments (Hurlbert 1984), and features of invertebrate populations such as spatial and temporal distribution patterns. However, some of the exclosure experiments conducted to date have been pseudoreplicated (Reise 1978, Schneider 1978, Duffy et al. 1981, Schneider \& Harrington 1981), unreplicated for a particular tidal level or sediment type (Botton 1984, Mercier \& McNeil 1994), have had cayes and predation areas separated by large distances (Kent \& Day 1983) or have inappropriately pooled samples for statistical analyses (Goss-Custard 1977. Wilson 1989, 1991a, 1994b, Mercier \& McNeil 1994). These studies, therefore, did not consider or confounded the spatial variability of invertebrate numbers with the effect of the shorebird predator. The conclusions from these studies should be carefully reconsidered in light of problems with their experimental design and/or statistical analyses.

In this paper I describe a shorebird exclosure experiment conducted on the Fraser River estuary, British Columbia, Canada, during the northward migration of the western sandpiper Calidris mauri. Replicate exclosure cages, with adjacent areas open to predation, were placed at 3 study sites that differed in their sediment characteristics (see Table 1) and in their use for feeding by shorebirds. Additional random sampling was conducted at the same study sites, before and after predation, to examine spatial variability in invertebrate distributions and the potential for detection of a predator effect without an exclusion device. This multifaceted approach, together with knowledge of the prey consumed by western sandpiper (K. Vermeer \& R. W. Elner unpubl. data), allowed a detailed examination of the effects of western sandpiper predation on the densities of their invertebrate prey.

\section{Western sandpiper Calidris mauri}

The western sandpiper is one of the commonest shorebirds of the western hemisphere, migrating in large flocks along the Pacific coast of North America to breeding grounds in the western subarctic of Alaska and eastern Siberia during the spring (Wilson 1994a).
Overwintering occurs in coastal areas of the Pacific, from California to Peru, and the Atlantic, from the southeastern United States to Surinam (Wilson 1994a). The primary migration route to the breeding grounds is along the Pacific coast of North America (O'Reilly \& Wingfield 1995), with stopover areas including San Francisco Bay (California), Grays Harbor (Washington), the Fraser River estuary (British Columbia), Chesterman Beach and Tofino mudflats (British Columbia), the Stikine River Delta (Alaska), and the Copper River Delta (Alaska) (Iverson et al. 1996). At the Fraser River estuary the northward migration is characterized by a peak in numbers in the period from mid-April to late May (Butler et al. 1987), with maximum numbers in 1992 occurring in the week of 26 to 29 April when $>500000$ shorebirds were present (Butler 1994). The greatest overall densities of western sandpiper were found on Roberts Bank, West Boundary Bay, and Sea Island (Butler 1994; for locations see Fig. 1). In contrast, the southward migration is spread over a longer time period (late June to early October; Butler et al. 1987), because of sex-and age-segregated movements by adult and juvenile shorebirds (Butler et al. 1987).

At stopover sites and at the wintering grounds, the main foods consumed by western sandpiper are marine benthic invertebrates such as arthropods, polychaete annelids and bivalve molluscs (Wilson 1994a) Preliminary studies in the Fraser River estuary have shown that molluscs (Macoma balthica, Batillaria zonalis), polychaetes (Nereis spp.) and crustaceans (amphipod: Corophium spp.i cumacean: Leucon subnasica; tanaid. Sinelobus stanfordi; podocopid ostracods) are present in the diet of western sandpiper (Vermeer \& Elner unpubl. data; see Table 2).

\section{METHODS}

Experimental work was carried out in spring (April to May) 1994 on the Fraser River estuary, near Vancouver, British Columbia, Canada (Fig. 1), during the northward migration of the western sandpiper Research was conducted at this time as the largest migrant population of shorebirds was present on the estuary during a discrete time period. Consequently. exclosure cages were present on the mudflat for only $1 \mathrm{mo}$, reducing the potential for long-term cage effects and the seasonal recruitment of marine invertebrates.

The 3 study sites were known feeding areas for western sandpipers (Butler 1994), differed in their sediment characteristics (Table 1), and had previously been used. in studies of invertebrate distributions (Elner unpubl. data). Two sites were on Roberts Bank (Westham Island and Brunswick Point), and a single site was in. 
Fig. 1 Fraser River estuary, British Columbia, Canada, showing locations of exclosure experiments at Boundary Bay (BOB), Brunswick Point (BRP) and Westham Isländ (WI), and random sampling at Brunswick PointUpper Roost (BRP-UR)

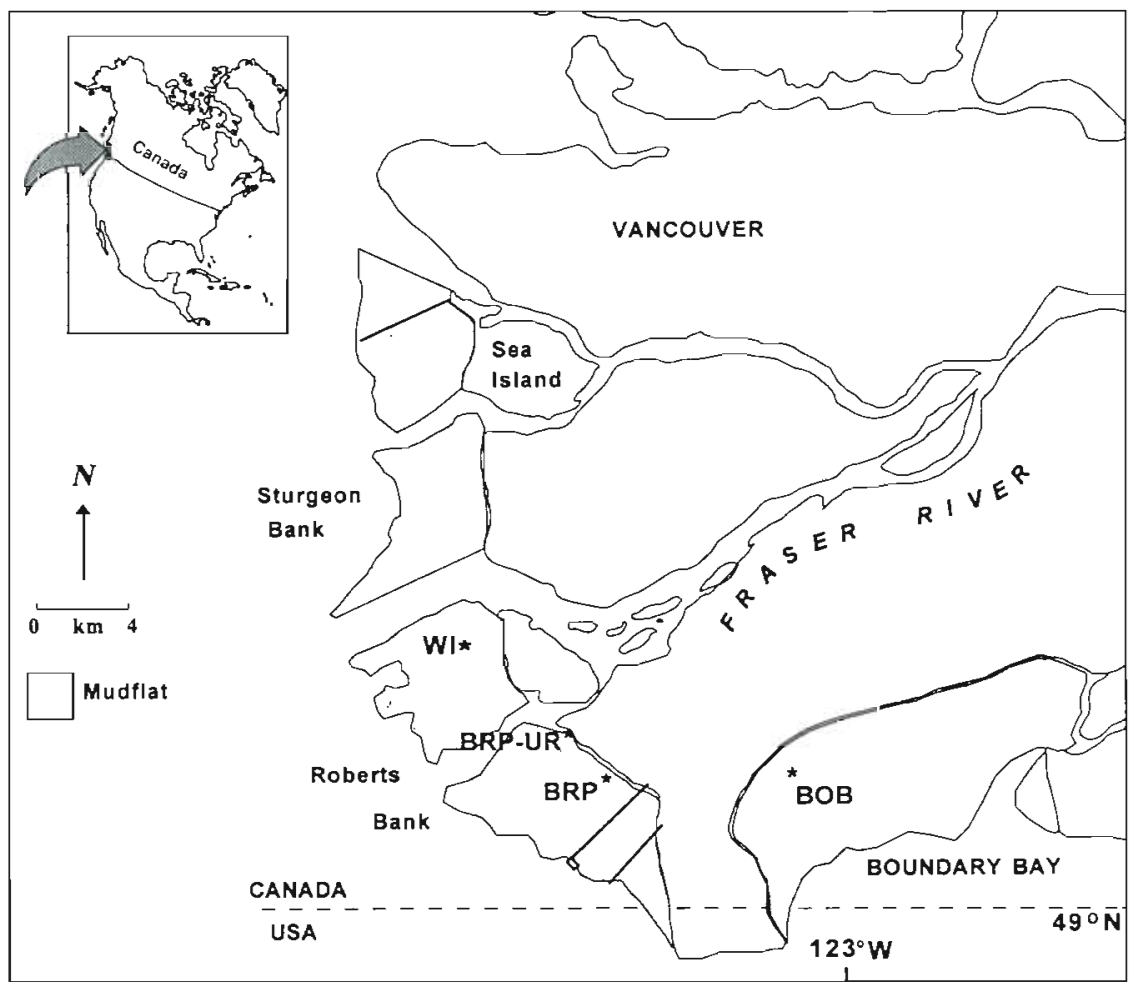

the western part of Boundary Bay (Fig 1). All locations were in the upper intertidal zone (Table 1).

At each site, 2 studies were conducted to test for an impact of western sandpiper predation on the invertebrate populations. The first was an exclosure experiment that prevented birds from foraging on small areas of mudflat; the second was a comparison of invertebrate numbers before and after the western sandpiper northward migration in an area adjacent to the exclosures.

Exclosure experiment. The exclosure design was modeled on that used by Wilson (1994b) in an experiment testing for an impact of predation by western sandpiper in Grays Harbor, Washington, USA. Each exclosure was constructed from 4 wooden stakes
$(0.6 \mathrm{~m}$ length) driven into the sediment in a $0.8 \times 0.6 \mathrm{~m}$ rectangular array until the top of the stake was $12 \mathrm{~cm}$ above the sediment surface. After sampling (see below) a roof of chicken wire (25 $\mathrm{mm}$ mesh) was stapled onto the top of the stakes. The height of the cage excluded western sandpiper (Wilson 1994b, author's pers. obs.); the open sides of the cage allowed predators other than shorebirds (e.g. crabs, fish) to enter the exclosure.

The exclosure cages (Cage $=$ Predation-) and unmarked open areas (Open = Predation + ) were arranged in a systematic design that ran parallel to the shoreline at the same tidal elevation. Five exclosure cages were spaced $5 \mathrm{~m}$ apart, as in Wilson (1994b),

Table 1. Characteristics of the 3 study sites used for exclosure experiments. Position: position of the exclosure cages. Tidal elevation: distance above Canadian chart datum (= the plane of lowest normal tides). Sediment type based on samples ( $\mathrm{N}=5$ ) taken at time of cage construction (Before, $\mathrm{S}^{\mathrm{B}}$; Fig. 2). Methods for determining sediment penetrability are described in the text

\begin{tabular}{|c|c|c|c|c|c|}
\hline Location & Position & Tidal elevation & $\begin{array}{l}\text { Sediment type } \\
\text { (median } \emptyset \text { ) }\end{array}$ & Mean $\%$ sand ${ }^{a}$ & $\begin{array}{l}\text { Sediment penetrability } \\
\text { mean } \pm \mathrm{SD}(\mathrm{cm})\end{array}$ \\
\hline Boundary Bay & $\begin{array}{r}49^{\circ} 03^{\prime} 04^{\prime \prime} \mathrm{N}, \\
123^{\circ} 01^{\prime} 18^{\prime \prime} \mathrm{W}\end{array}$ & $+3.2 \mathrm{~m}$ & 2.73 & 99.4 & $8.39 \pm 4.10$ \\
\hline Brunswick Point & $\begin{array}{r}49^{\circ} 03^{\prime} 07^{\prime \prime} \mathrm{N} \\
123^{\circ} 08^{\prime} 31^{\prime \prime} \mathrm{W}\end{array}$ & $+2.6 \mathrm{~m}$ & $>4.0$ & 46.5 & $13.42 \pm 1.00$ \\
\hline Westham Island & $\begin{array}{r}49^{\circ} 05^{\prime} 40^{\prime \prime} \mathrm{N} \\
123^{\circ} 12^{\prime} 41^{\prime \prime} \mathrm{W}\end{array}$ & $+1.8 \mathrm{~m}$ & 3.15 & 69.7 & $8.81 \pm 1.34$ \\
\hline
\end{tabular}


with the 12 open areas interspersed systematically around them (Fig. 2A). A similar arrangement of Predation-/Predation + treatments was used by Hurlbert \& Chang (1983), with the rationale that if the birds avoid the exclosure cages, randomly varying the distance between the exclosures would lead to increased variability among open areas in their use by birds (Hurlbert 1984). Open areas (Predationt) were $3 \mathrm{~m}$ shoreward or seaward from the centre of the exclosure cage (Predation-), spaced $5 \mathrm{~m}$ apart in a horizontal pattern offset by $2.5 \mathrm{~m}$. from the exclosure cages (Fig. 2A).

Exclosure cages were positioned on the mudflat in the period of low tides (11 to 15 April 1994) prior to the arrival of western sandpiper on the Fraser River estuary. Once the stakes were in the sediment, three $10 \mathrm{~cm}$ diameter by $10 \mathrm{~cm}$ deep cores were taken at 3 of the 4 corners of the cage as determined by a coin toss (UL/UR/LR or UR/LR/LL; Fig. 2B) to provide a Before sample for the exclosure cage. These cores were taken immediately outside the exclosure cage to avoid disturbance to the central part of the cage which would be used in the After sampling. The initial sediment sample was taken approximately $5 \mathrm{~cm}$ into the cage at the remaining corner $\left(S^{B}\right.$; Fig. $2 B$ ) as described below. Plant material, such as Zostera or filamentous algae, that was caught in the mesh of the

\section{A}
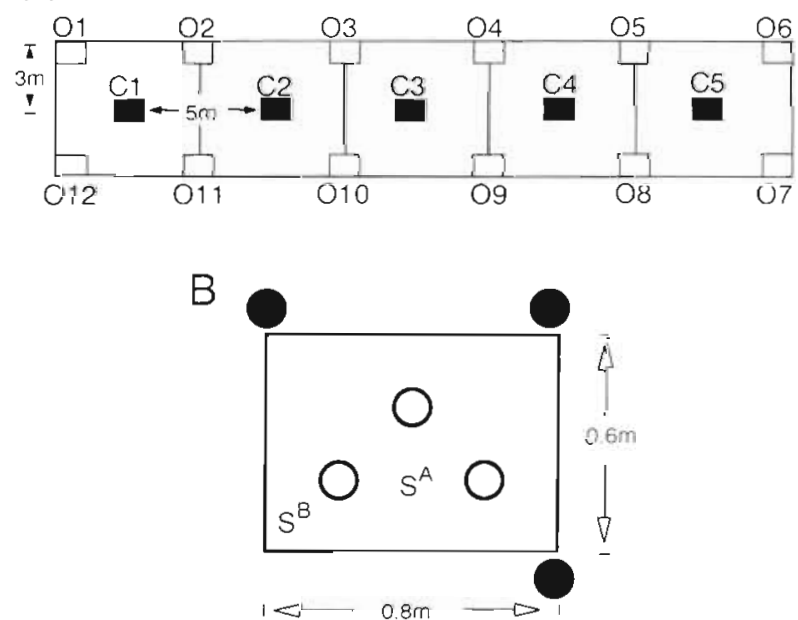

Fig. 2. (A) Arrangement of exclosure Cages ( $\mathrm{Cl}$ to $\mathrm{C} 5$ ) and Open areas (O1 to 012 ) at each study site. Exclosure Cages and Open areas were spaced $5 \mathrm{~m}$ apart at the same tidal elevation. Square areas surrounding each exclosure Cage (bordered by e.g. O1-O2-O11-O12) are the zones in which shorebird faeces were censused. (B) Sampling protocol for each exclosure Cage or Open area. The $0.8 \times 0.6 \mathrm{~m}$ area was sampled for sediments at the beginning and end of the experiment $\left(S^{\beta}, S^{h}\right.$ respectively) and for invertebrates. Samples taken at the beginning of the experiment (Before) were at 3 of the corners of the exclosure Cage (O); at the end of the experiment (After) 3 cores were taken inside the exclosure Cage and in Open areas $(O)$ exclosure cages was removed during regular visits to each study site.

After western sandpipers had migrated north of the Fraser River estuary, the experiment was completed by sampling three $10 \mathrm{~cm}$ diameter $(10 \mathrm{~cm}$ deep) invertebrate cores and a single sediment core $\left(\mathrm{S}^{\mathrm{A}}\right)$ within each exclosure cage as shown in Fig 2B. The Open areas, available for feeding by western sandpiper, were sampled for invertebrates in the same manner using a $0.8 \times$ $0.6 \mathrm{~m}$ rectangular quadrat to define the position of the cores. Sampling was completed during the low tide period of 25 to 27 May 1994

All invertebrate samples were frozen immediately after returning to the laboratory. Defrosted sediments were later sieved through a $500 \mu \mathrm{m}$ mesh screen to remove the macrofauna, and the invertebrates preserved in $85 \%$ ethanol. Invertebrates were sorted to the species level, where possible, using reference collections from a previons study (EIner unpubl. data).

Bird feeding around exclosures: Evidence for shorebird predation in the region of the exclosure experiment was collected throughout the period of western sandpiper migration (19 April to 12 May 1994) A rectangular grid $(29 \times 6 \mathrm{~m})$ was placed around the exclosure cages, including the unmarked Open areas, and marked with pieces of bamboo stake that protruded $5 \mathrm{~cm}$ from the sediment surface (Fig. 2A). Visits were made to each exclosure area every $2 \mathrm{~d}$ at low tide and counts made of the number of shorebird faeces in the $29 \times 6 \mathrm{~m}$ rectangle. The same route was used from the shore to the exclosure cage to minimize the effects of human footprints on shorebird feeding. Tests showed that faeces were removed on subsequent high tides at all locations (author's unpubl data), so counts made on a survey were evidence for presence of shorebirds in the exclosure area on that low tide period. Larger faeces produced by birds such as gulls and herons were excluded from the counts.

Observations on western sandpiper feeding and the presence of faeces showed that birds did not avoid the exclosures but fed adjacent to and betwon the cages (R. Butler, M. Lemon, and author's pers. obs.)

Sediment analyses: Sediment samples were collected at each study site using cores constructed from $30 \mathrm{cc}$ disposable syringes $17.4 \mathrm{~mm}$ diameter, $105 \mathrm{~mm}$ length). Cores were taken from the inside corner of the cage at the beginning of the experiment $\left(S^{B}\right)$ and from the centre of the cage at the end of the experiment $\left(\mathrm{S}^{\mathrm{A}}\right.$; Fig 2B). Samples were frozen in the syringe after returning from the field and stored until analysis. The upper $3 \mathrm{~cm}$ of the core was cut, the sediments dried in a freeze-drier, and particle size analysis performed using standard techniques (Holme \& McIntyre 1984). To determine if there was a change in the seciment composition within the exclosure cages during the 
experiment, the proportion of silt $(<63 \mu \mathrm{m})$ was compared for the Before/After samples at each site using a paired sample t-test.

An index of sediment penetrability was obtained in the $29 \times 6 \mathrm{~m}$ gridded area surrounding the exclosure cages (Fig. 2A) following the method of Kalejta \& Hockey (1991). The depth of penetration of a standard 4.8 mm diameter brass rod $(0.76 \mathrm{~m}$ length, $115 \mathrm{~g}$ weight) is measured after being dropped down a $1.5 \mathrm{~m}$ PVC tube. The reported index of penetrability is the mean of 10 measurements made in a range of substrate conditions (wetness, texture, etc.) within the grid.

Before and After study. Random sampling to test for changes in invertebrate numbers, without an exclosure device, was conducted at the 3 study sites (Boundary Bay, Brunswick Point, Westham Island; Fig. 1) on 1 occasion before (Before; 11 to 15 April) and 1 occasion after the northward migration (After; 25 to 27 May). Sampling was conducted during the same low-tide period as the exclosure experiment at all study sites except Westham Island Before.

Random samples were collected in an area approximately $100 \mathrm{~m}$ from Cage 5 at the same tidal elevation as the exclosure experiment. Three sites (A to C) were spaced $100 \mathrm{~m}$ apart and marked for the duration of the northward migration of western sandpipers with a wooden stake. At each sampling (Before/After) 3 plots were randomly chosen within each site using a random compass direction and a distance $(0$ to $50 \mathrm{~m}$ ) from the centre stake. In each plot 3 cores were taken within a $0.8 \times 0.6 \mathrm{~m}$ area, equivalent to the size of the exclosure cage, resulting in a total of 27 cores ( 3 sites $x 3$ plots $x$ 3 cores) Before and 27 cores After the period of predation at each study site.

In addition to the study sites used for the exclosure experiments, random sampling was conducted at a western sandpiper roost site at Brunswick Point (Brunswick Point-Upper Roost; Fig. 1). This location was adjacent to the salt marsh and was the last part of the shore at Brunswick Point to be covered by the incoming tide. Large numbers of western sandpiper fed in this area (density of faeces and peck/probe marks; author's unpubl. obs.) prior to roosting in the saltmarsh or adjacent fields. Samples were taken Before (19 April) and After (30 May) the northward migration using the sampling protocol described above.

Statistical analyses. Statistical analyses were performed on species that were present in at least $65 \%$ of the total 66 cores collected in the exclosure experiment and/or were known to be consumed by western sandpiper (Vermeer \& Elner unpubl. data; Table 2). The 2 exceptions to the former criteria were Macoma balthica at Boundary Bay (39\% of cores) and gammarid amphipods at Westham Island (57\% of cores). These species were included because of their potential importance in the western sandpiper diet. The measured variable in all analyses was the number of invertebrates per $10 \mathrm{~cm}$ core, transformed by $\log _{10}(x+1)$ to

Table 2. Range in number of invertebrates per core for species used in analyses at each study site. Diet: asterisk denotes presence of species in stomach contents of western sandpiper from these locations (Vermeer \& Elner unpubl. data). Cage Before: range in cores from exclosure Cages 1 to 5 in April $1994(\mathrm{~N}=15)$. Cage After: range in cores from exclosure Cages 1 to 5 in May $1994(\mathrm{~N}=15)$. Open After: range in cores from Open areas 1 to 12 exposed to shorebird predation in May 1994 ( $\mathrm{N}=36$ )

\begin{tabular}{|c|c|c|c|c|c|}
\hline Location & Species & Diet & Cage Before & Cage After & Open After \\
\hline Boundary Bay & $\begin{array}{l}\text { Batillaria zonalis } \\
\text { Macoma balthica } \\
\text { Eteone spp. } \\
\text { Manayunkia aestuarina } \\
\text { Podocopid ostracod }\end{array}$ & $\dot{.}$ & $\begin{array}{l}0-14 \\
0-5 \\
0-5 \\
0-3 \\
5-49\end{array}$ & $\begin{array}{l}0-6 \\
0-1 \\
1-6 \\
0-5 \\
1-14\end{array}$ & $\begin{array}{l}0-11 \\
0-3 \\
0-4 \\
0-10 \\
2-174\end{array}$ \\
\hline Brunswick Point & $\begin{array}{l}\text { Macoma balthica } \\
\text { Manayunkia aestuarina } \\
\text { Eteone spp. } \\
\text { Hobsonia florida } \\
\text { Leucon subnasica } \\
\text { Sinelobus stanfordi } \\
\text { Corophium spp. }\end{array}$ & . & $\begin{array}{c}6-18 \\
25-699 \\
0-5 \\
4-27 \\
6-97 \\
7-58 \\
0-14\end{array}$ & $\begin{array}{l}4-15 \\
1-574 \\
0-3 \\
2-20 \\
0-42 \\
1-102 \\
1-37\end{array}$ & $\begin{array}{l}2-15 \\
3-361 \\
0-6 \\
1-24 \\
2-96 \\
1-31 \\
1-31\end{array}$ \\
\hline Westham Island & $\begin{array}{l}\text { Macoma balthica } \\
\text { Mya arenaria } \\
\text { Manayunkia aestuarina } \\
\text { Hobsonia florida } \\
\text { Leucon subnasica } \\
\text { Sinelobus stanfordi } \\
\text { Corophium spp. } \\
\text { Gammarids }\end{array}$ & . & $\begin{array}{l}18-51 \\
0-10 \\
54-1044 \\
1-31 \\
5-41 \\
0-34 \\
8-39 \\
0-11\end{array}$ & $\begin{array}{c}23-45 \\
0-4 \\
10-654 \\
6-33 \\
0-6 \\
1-17 \\
2-27 \\
0-6\end{array}$ & $\begin{array}{l}26-56 \\
0-5 \\
7-926 \\
2-28 \\
0-18 \\
0-34 \\
0-28 \\
0-10\end{array}$ \\
\hline
\end{tabular}


conform to the assumptions of ANOVA. Separate analyses were completed for each study site using PCSAS Release 6.03.

Exclosure experiment: The statistical analysis for the exclosure experiment was completed in 2 parts:

(1) The effect of the exclosure cage on invertebrate numbers with no predation by shorebirds (cage effects). The analysis compared invertebrate numbers in the cores taken at the corners of the cage prior to migration (Before) with those taken inside the exclosure cage after the period of predation (After). For each study site and species, differences in invertebrate numbers were compared Before and After predation (B/A), and among exclosure cages (Cage), using a 2way analysis of variance. The model used in the ANOVA was:

$$
X_{1 j k}=\mu+\mathrm{B} / \mathrm{A}_{1}+\mathrm{Cage}_{j}+\mathrm{B} / \mathrm{A} \times \mathrm{Cage}_{i j}+e_{k(i j)}
$$

Both factors were fixed; the effect of all factors was examined against the residual error.

(2) The impact of western sandpiper predation on invertebrate numbers was tested using a nested analysis of variance. For each study site and species, differences in invertebrate numbers were compared in cores taken inside exclosure cages (Predation-) with those in areas open to predation by shorebirds (Predationt) in the After sampling. The model used in the ANOVA was:

$X_{i j k}=\mu+$ Predation- $/ t_{1}+$ Position(Predation $-/+j_{j[i]}+e_{k(i j)}$ where Predation = exclosure Cage (Predation-) or Open area (Predation+), and Position = the location of that treatment (Predation- or Predation+) within the predation array (see Fig. 2A). The effect of the Predation-/+ term was examined against the nested term Position(Predation $-/+$ ) and the effect of Position(Predation $-/+$ ) examined against the residual error.

Before and After study: For each study site and species, differences in invertebrate numbers were compared Before and After predation, among sites, and among plots nested within sites using a mixed model analysis of variance. In this analysis the factor Before/After predation was fixed, with Site (A to C) a random factor, orthogonal to time, and Plot a random factor, nested within Site. The model used in the ANOVA was:

$$
\begin{gathered}
X_{i j k}=\mu+\mathrm{B} / \mathrm{A}_{i}+\text { Site }_{j}+\mathrm{B} / \mathrm{A} \times \text { Site }_{l j}+\operatorname{Plot}(\text { Site })_{k i j)} \\
+\mathrm{B} / \mathrm{A} \times \operatorname{Plot}(\text { Site })_{k(k)}+e_{k(i j)}
\end{gathered}
$$

The effect of western sandpiper predation (B/A) was tested against the interaction term $\mathrm{B} / \mathrm{A} \times \mathrm{Site}_{\mathrm{i}}$ the effect of Site against the term Plot(Site); the effect of $\mathrm{B} / \mathrm{A} \times$ Site against the interaction term $\mathrm{B} / \mathrm{A} \times \mathrm{Plot}($ Site); and the effects of Plot and B/A $\times$ Plot(Site) were tested against the residual error.

\section{RESULTS}

A summary of the relative abundances of the infaunal invertebrates throughout the Fraser River estuary is given in Table 2. The same general suite of marine invertebrates was found at all study sites, except for the gastropod Batillaria zonalis and podocopid ostracods which were found in Boundary Bay only (Table 2). The most numerically abundant species was the small sabellid polychaete Manayunkia aestuarina (size 0.5 to $3 \mathrm{~mm}_{i}$ Eckman 1979) which forms dense mats of tubes at Brunswick Point and Westham Island, and is rare at Boundary Bay. Other abundant species included the terebellid polychaete Hobsonia florida, the crustaceans Leucon subnasica, Sinelobus stanfordi, Corophium spp. and other gammarid amphipods (Table 2)

\section{Exclosure experiment}

$$
\text { Cage effects }
$$

Sediment analyses. The 3 study sites used for the exclosure experiment had different sediment characteristics (Table 1). The sediments in Boundary Bay were almost exclusively sand, with $<1 \%$ silt, and the lowest mean penetrability (Table 1). Penetrability was, however, higher in wetter areas (maximum $16.7 \mathrm{~cm}$ ). A high percentage of sand was also found in sediments at Westham Island, with a similar penetrability to that observed at Boundary Bay (Table 1). The 'muddiest' site was Brunswick Point, with over $50 \%$ of each sample in sediments <63 $\mu \mathrm{m}$ (Table 1). The combination of fine sediments and a high water content in the sediment resulted in the highest index of penetrability (Table 1).

There was no significant change in the percentage of silt in sediment samples taken at the beginning and end of the exclosure experiment at any of the 3 study sites $\left(\mathrm{S}^{\mathrm{A}}\right.$ vs $\mathrm{S}^{\mathrm{B}}$, paired $t$-tests: Boundary Bay, $t=0.256$ Brunswick Point, $t=0.148$; Westham Island, $t=0.867$ $\mathrm{df}=4, \mathrm{p}>0.05)$. This suggests that, on the time scale of the exclosure experiment, there was no alteration in sediment composition resulting from the hydrodynamic effect of the exclosure cage.

Deep excavations (ca $5 \mathrm{~cm}$ deep) were observed at the corners of each exclosure cage at Westham Island. This scouring resulted from high current flow at this site, but did not affect the central area of the cage used for the After invertebrate and sediment samples (see Fig. 2B).

Invertebrates. Changes to the invertebrate numbers in the exclosure cages are described below for the studied species at each study site. In addition, the crab 
Table 3. Analyses of variance of the number of invertebrates per core $\left[\log _{10}(x+1)\right.$ transformed] for species at the 3 study sites Two-way ANOVAs with factors: Before/After (B/A), samples from April and May 1994; Cage, exclosure cage 1 to 5; and the interaction term $B / A \times$ Cage. Degrees of freedom for $F: B / A=1,20 ;$ Cage $=4,20 ; B / A \times C a g e=4,20$. See model statement in 'Methods' Significant p-values are shown in bold. Gammarids includes all amphipods except Corophium spp.

\begin{tabular}{|c|c|c|c|c|c|c|c|}
\hline \multirow[t]{2}{*}{ Location } & \multirow[t]{2}{*}{ Species } & \multicolumn{2}{|c|}{$\mathrm{B} / \mathrm{A}$} & \multicolumn{2}{|c|}{ Cage } & \multicolumn{2}{|c|}{$\mathrm{B} / \mathrm{A} \times$ Cage } \\
\hline & & $F$ & $\mathrm{p}$ & $F$ & $p$ & $F$ & $\mathrm{p}$ \\
\hline \multirow[t]{5}{*}{ Boundary Bay } & Batillaria zonalis & 9.91 & 0.005 & 0.60 & 0.670 & 1.95 & 0.142 \\
\hline & Macoma balthica & 4.62 & 0.044 & 1.46 & 0.251 & 0.95 & 0.454 \\
\hline & Eteone spp. & 3.35 & 0.082 & 1.32 & 0.298 & 0.42 & 0.793 \\
\hline & Manayunkia aestuarina & 0.01 & 0.938 & 2.81 & 0.053 & 0.92 & 0.473 \\
\hline & Podocopid ostracod & 19.37 & 0.0003 & 1.05 & 0.405 & 0.90 & 0.484 \\
\hline \multirow[t]{7}{*}{ Brunswick Point } & Macoma balthica & 6.22 & 0.022 & 1.78 & 0.172 & 2.41 & 0.083 \\
\hline & Manayunkia aestuarina & 4.77 & 0.041 & 1.39 & 0.272 & 1.48 & 0.247 \\
\hline & Eteone spp. & 1.13 & 0.301 & 0.64 & 0.641 & 1.38 & 0.278 \\
\hline & Hobsonia florida & 0.95 & 0.340 & 4.23 & 0.012 & 0.71 & 0.597 \\
\hline & Leucon subnasica & 6.24 & 0.021 & 0.98 & 0.440 & 0.98 & 0.441 \\
\hline & Sinelobus stanfordi & 16.85 & 0.0006 & 3.94 & 0.016 & 1.88 & 0.153 \\
\hline & Corophium spp. & 12.92 & 0.002 & 3.31 & 0.031 & 0.69 & 0.610 \\
\hline \multirow[t]{8}{*}{ Westham Island } & Macoma balthica & 1.08 & 0.311 & 0.85 & 0.512 & 0.91 & 0.478 \\
\hline & Mya arenaria & 0.15 & 0.699 & 0.40 & 0.803 & 2.02 & 0.131 \\
\hline & Manayunkia aestuarina & 4.26 & 0.052 & 0.65 & 0.632 & 0.54 & 0.707 \\
\hline & Hobsonia florida & 0.07 & 0.795 & 3.20 & 0.035 & 1.01 & 0.427 \\
\hline & Leucon subnasica & 116.28 & 0.0001 & 0.84 & 0.514 & 0.66 & 0.627 \\
\hline & Sinelobus stanfordi & 0.28 & 0.600 & 3.17 & 0.036 & 0.83 & 0.523 \\
\hline & Corophium spp. & 3.31 & 0.084 & 1.00 & 0.429 & 0.12 & 0.973 \\
\hline & Gammarids & 0.20 & 0.657 & 0.27 & 0.895 & 1.14 & 0.368 \\
\hline
\end{tabular}

Hemigrapsus spp., which was absent in the Before samples, was found under the exclosure cages at Boundary Bay and Brunswick Point at the end of the experiment.

(A) Boundary Bay. Five invertebrate species or taxa were examined in Boundary Bay, with significant differences in invertebrate numbers in the area immediately outside (Before, April) and inside the exclosure cage (After, May) in 3 of the species (Table 3). In these 3 species there was a decline in mean numbers between the 2 sampling dates (Fig. 3). This was most marked in the gastropod Batillaria zonalis and podocopid ostracods in which the maximum number per core decreased by a factor of 2 between April and May (Table 2). Similarly, Macoma balthica showed a significant B/A effect (Table 3) with a decline in mean numbers (Fig. 3). However, in $M$. balthica the mean number per core was usually $<1$ and no individuals were found at Cage 4 on either sampling date (Fig. 3).

(B) Brunswick Point. Significant B/A effects were found in 5 of the 7 species examined at this study site (Table 3). Again there was a trend for a decline in invertebrate numbers between the April and May sampling dates, except for Corophium spp. (Fig. 4). The significant B/A differences in less mobile species such as Macoma balthica, and the sabellid polychaete Manayunkia aestuarina (Table 3, Fig. 4), probably occurs because the Before samples outside the exclo-
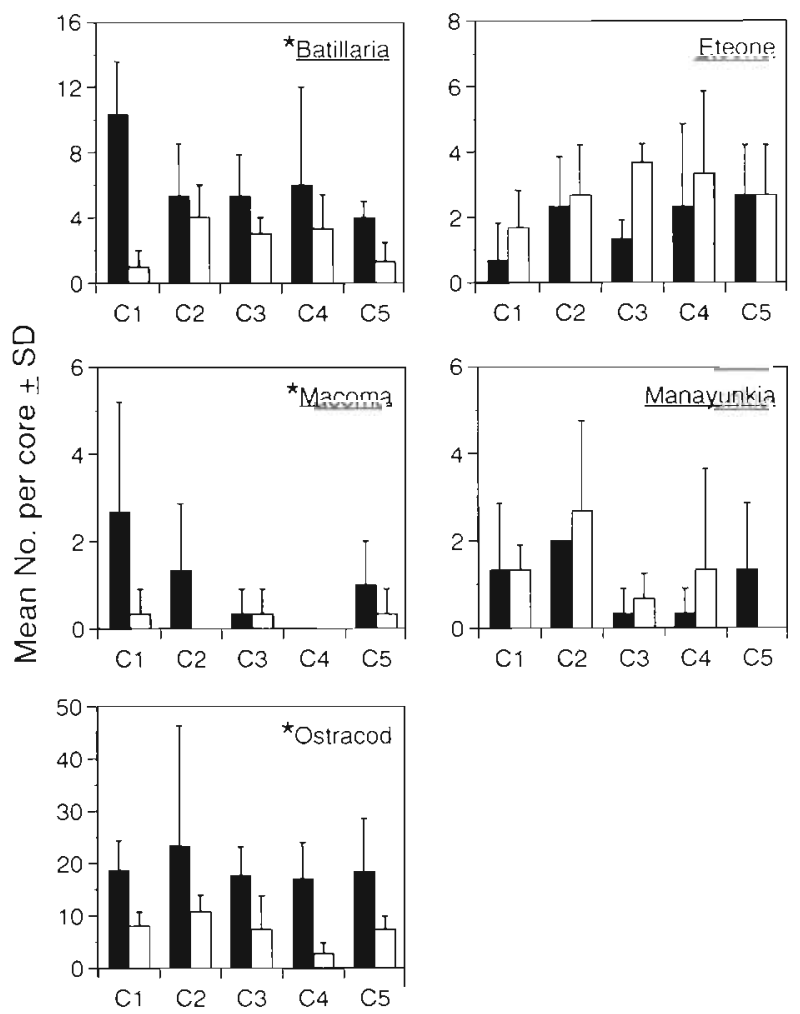

Fig. 3. Invertebrate numbers in Cages 1 to 5 at the beginning (Before, solid bars) and end (After, open bars) of the exclosure experiment from Boundary Bay. Asterisk proor to species name denotes a significant B/A effect in the ANOVA (Table 3) 

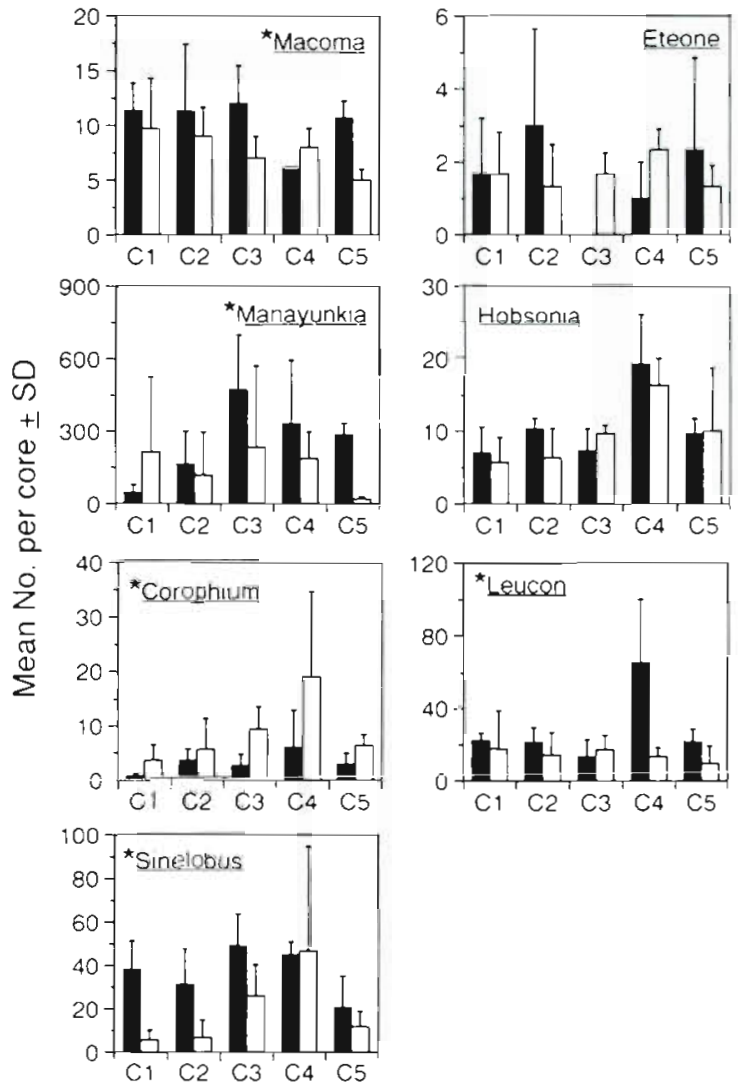

Fig. 4. Invertebrate numbers in Cages 1 to 5 at the beginning (Before, solid bars) and end (After, open bars) of the exclosure experiment from Brunswick Point. Asterisk prior to species name denotes a significant B/A effect in the ANOVA (Table 3)

sure cage did not provide a good estimate of numbers inside. Although declines were seen in most cages, there were $\mathrm{B} / \mathrm{A}$ increases in Cage 4 for $M$. balthica and Cage 1 in $M$. aestuarina (Fig. 4). Evidence for this small-scale patchiness was also seen in the terebellid polychaete Hobsonia florida, which showed a significant difference between cages (Table 3, Fig. 4).

The remaining species that showed significant B/A differences are all mobile crustaceans: the cumacean Leucon subnasica, the tanaid Sinelobus stanfordi, and the gammarid amphipod Corophium spp. (Table 3. Fig. 4). Generally, numbers declined between Before and After samples ( $L$. subnasica, S. stanfordi Fig. 4). However, in Corophium spp. numbers per core increased up to 3 -fold during the experiment (Table 2 , Fig. 4). In the latter species, there was also a significant difference between cages (Table 3).

(C) Westham Island. A significant B/A effect was found in 1 species (Table 3 ), the cumacean Leucon subnasica, for which numbers decreased in May to $10 \%$ of the April value (Table 2, Fig 5). There were, however, significant differences between cages in the
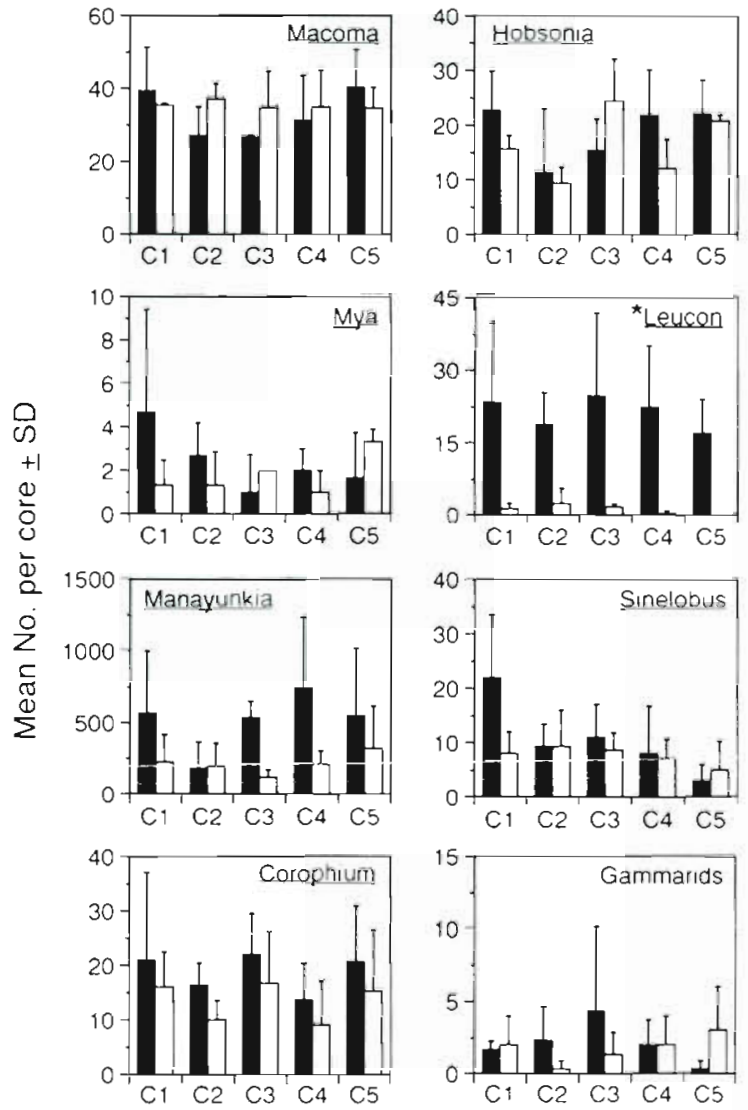

Fig. 5. Invertebrate numbers in Cages 1 to 5 at the beginning (Before, solid bars) and end (After, open bars) of the exclosure experiment from Westham Island. Asterisk prior to specles name denotes a significant B/A effect in the ANOVA (Table 3)

terebellid polychaete Hobsonia florida and the tanaid Sinelobus stanfordi (Table 3, Fig. 5)

Predation effect

Evidence for predation by western sandpiper. Counts of western sandpiper faeces were made from 19 April to 12 May 1994, to provide a semi-quantitative index of the use by shorebirds of the respective study sites. Feeding western sandpiper produce a faecal pellet every 1 to $3 \mathrm{~min}$ (R. Butler pers. comm.), so that faeces within the census area were likely produced from food obtained at that study site, if not in the immediate area surrounding the exclosure cages. This index is an alternate measure to directly observing shorebirds feeding at the study site.

Using the total number of faeces in the $29 \times 6 \mathrm{~m}$ census area as an index of shorebird predation, the sites are ranked in descending order. Westham Island, Brunswick Point, Boundary Bay (Table 4). There was little evidence for predation at the Bound- 
Table 4. Calidris mauri. Index of predation by western sandpiper in the gridded area around the exclosure experiment at the 3 study sites in the period 19 April to 12 May 1994. Numbers presented are number of faeces in the $29 \times 6 \mathrm{~m}$ census area $\left(174 \mathrm{~m}^{2}\right)$

\begin{tabular}{|lcccccc|}
\hline Location & Mean & SD & $\begin{array}{c}\text { No. of days } \\
\text { censused (N) }\end{array}$ & $\begin{array}{c}\text { Minimum no. of } \\
\text { faeces in area }\end{array}$ & $\begin{array}{c}\text { Maximum no. of } \\
\text { faeces in area }\end{array}$ & $\begin{array}{c}\text { No. of days } \\
\text { with no faeces }\end{array}$ \\
\hline Boundary Bay & 0.54 & 0.97 & 13 & 0 & 3 & 9 \\
Brunswick Point & 34.18 & 47.10 & 11 & 0 & 156 & 1 \\
Westham Island & 50.1 & 46.6 & 10 & 0 & 116 & 1 \\
\hline
\end{tabular}

ary Bay site as there were no faeces in the exclosure area on almost $70 \%$ of the censused days (Table 4 ). Westham Island and Brunswick Point had similar levels of predation, although the date with the maximum number of faeces differed (30 April and 6 May respectively). In both cases the single day with no faeces occurred in late May after the majority of western sandpipers had migrated north of the Fraser River estuary.

The ranking of the sites for western sandpiper feeding using the faecal index correlates with observations of western sandpiper flocks in the Fraser River estuary. As the tide rises, flocks of western sandpiper feeding at Westham Island fly south to Brunswick Point where they feed until the rising water covers the mudflats. Flocks then fly to Boundary Bay, or remain at Brunswick Point, to roost in agricultural fields adjacent to the mudflats. On the ebbing tide flocks of western sand- piper return to Brunswick Point and then to Westham Island (R. Butler pers. comm.). Thus, the primary feeding sites are at Westham Island and Brunswick Point. The low number of faeces at the high shore Boundary Bay site probably reflects the low use of this area for feeding

No western sandpiper faeces were observed inside the exclosure cages, suggesting that the exclosures were effectively excluding the shorebird predator.

Invertebrates. (A) Boundary Bay. A significant difference in invertebrate numbers between Cage (Predation-) and areas Open (Predation+) to predation by western sandpiper was found in only 1 species at Boundary Bay, the phyllodocid polychaete Eteonespp. (Table 5). Although there were lower numbers of Eteone spp. in the Open area outside the exclosure (Fig. 6), this difference occurred at a study site with little evidence of shorebird predation (Table 4).

Table 5. Analyses of variance of the number of invertebrates per core $\left[\log _{10}(x+1)\right.$ transformed $\mid$ for species at the 3 study sites. Nested ANOVAs with factors: Predation-/+, exclosure Cage or Open area in May 1994; Position(Predation-/+). Degrees of freedom for $F$ : Predation $-1+=1,15$; Position(Predation $-/+$ ) $=15,34$. See model statement in 'Methods' Significant p-values are shown in bold. Gammarids includes all amphipods except Corophium spp.

\begin{tabular}{|c|c|c|c|c|c|}
\hline \multirow[t]{2}{*}{ Location } & \multirow[t]{2}{*}{ Species } & \multicolumn{2}{|c|}{ Predation-/+ } & \multicolumn{2}{|c|}{ Position(Predation $-/+$ ) } \\
\hline & & $F$ & $\mathrm{p}$ & $F$ & $\mathrm{p}$ \\
\hline \multirow[t]{5}{*}{ Boundary Bay } & Batillaria zonalis & 0.39 & 0.541 & 1.94 & 0.054 \\
\hline & Macoma balthica & 3.06 & 0.101 & 1.66 & 0.108 \\
\hline & Eteone $\mathrm{spp}$ & 14.86 & 0.0016 & 0.65 & 0.815 \\
\hline & Manayunkia aestuarina & 1.62 & 0.222 & 1.17 & 0.339 \\
\hline & Fodocopid ostracod & 0.66 & 0.430 & 0.99 & 0.482 \\
\hline \multirow[t]{7}{*}{ Brunswick Pount } & Macoma balthica & 0.36 & 0.559 & 1.80 & 0.076 \\
\hline & Manayunkia aestuarina & 0.96 & 0.342 & 0.81 & 0.656 \\
\hline & Eteone spp. & 0.02 & 0.898 & 0.71 & 0.758 \\
\hline & Hobsonia florida & 1.01 & 0.331 & 1.71 & 0.096 \\
\hline & Leucon subnasica & 2.76 & 0.117 & 0.71 & 0.757 \\
\hline & Sinelobus stanfordi & 0.75 & 0.402 & 1.96 & 0.051 \\
\hline & Corophium spp. & 0.03 & 0.857 & 1.96 & 0.052 \\
\hline \multirow[t]{8}{*}{ Westham Island } & Macoma balthica & 0.44 & 0.516 & 0.73 & 0.735 \\
\hline & Mya arenaria & 0.01 & 0.923 & 1.65 & 0.111 \\
\hline & Manayunkla aestuarina & 1.65 & 0.219 & 0.46 & 0.944 \\
\hline & Hobsonia florida & 2.44 & 0.139 & 1.39 & 0.207 \\
\hline & Leucon subnasica & 0.66 & 0.430 & 1.38 & 0.211 \\
\hline & Sinelobus stanfordi & 2.54 & 0.132 & 1.06 & 0.428 \\
\hline & Corophium spp. & 1.84 & 0.196 & 2.60 & 0.010 \\
\hline & Gammarids & 0.19 & 0.671 & 1.99 & 0.048 \\
\hline
\end{tabular}




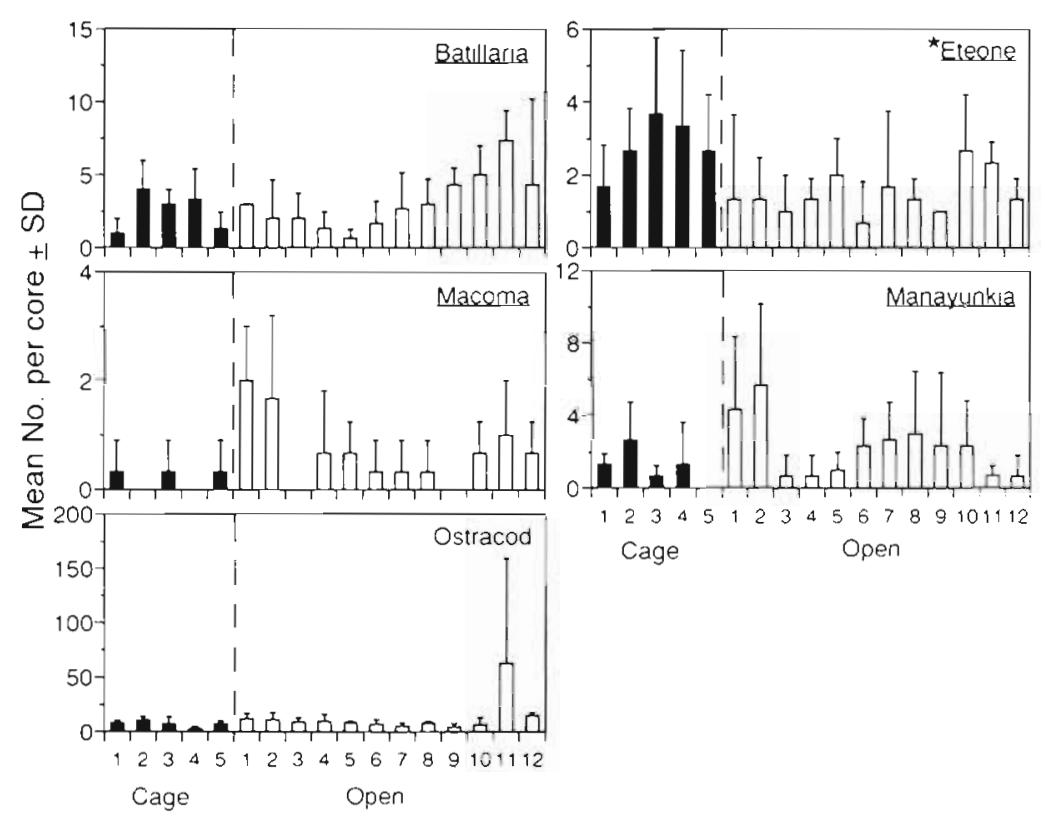

Fig. 6. Invertebrate numbers in $\mathrm{Cages}$ ( $\mathrm{C} 1$ to $\mathrm{C} 5$, solid bars) and Open areas (O1 to 12 , open bars) after the period of western sandpiper predation at Boundary Bay. Dashed line separates Cage and Open areas. Asterisk prior to species name denotes a significant Predation ettect in the ANOVA (Table 5)
(B) Brunswick Point. No significant Predation-1+ effects were seen at Brunswick Point (Table 5), which showed a high index of use for feeding by western sandpiper (Table 4). There were also no significant differences in invertebrate numbers in replicate Cage or Open areas [Position(Predation-/t); Table 5]. High variability was seen in the mean numbers per core for the polychaetes (Manayunkia aestuarina, Hobsonia florida) and the crustaceans (Corophium spp. Leucon subnasica, Sinelobus stanfordi) in both Cage and Open areas (see SD error bars in Fig. 7).

(C) Westham Island. This site, with the highest index of predation (Table 4) had no significant Predation-/+ effects (Tahle 5) Significant Position(Proda tion $-/+$ ) differences were observed in Corophium spp. and gammarid amphipods (Fig. 8). In both cases, numbers per core were higher in Open areas 1 to 4,11 and 12 , on the left half of the predation array (see Fig. 2A). The other species

The other species tested showed non-significant Predation-/+ effects (Table 5). Cages and Open areas showed a high degree of variability and often showed increases in invertebrate numbers in the presence of predation (Fig. 6).

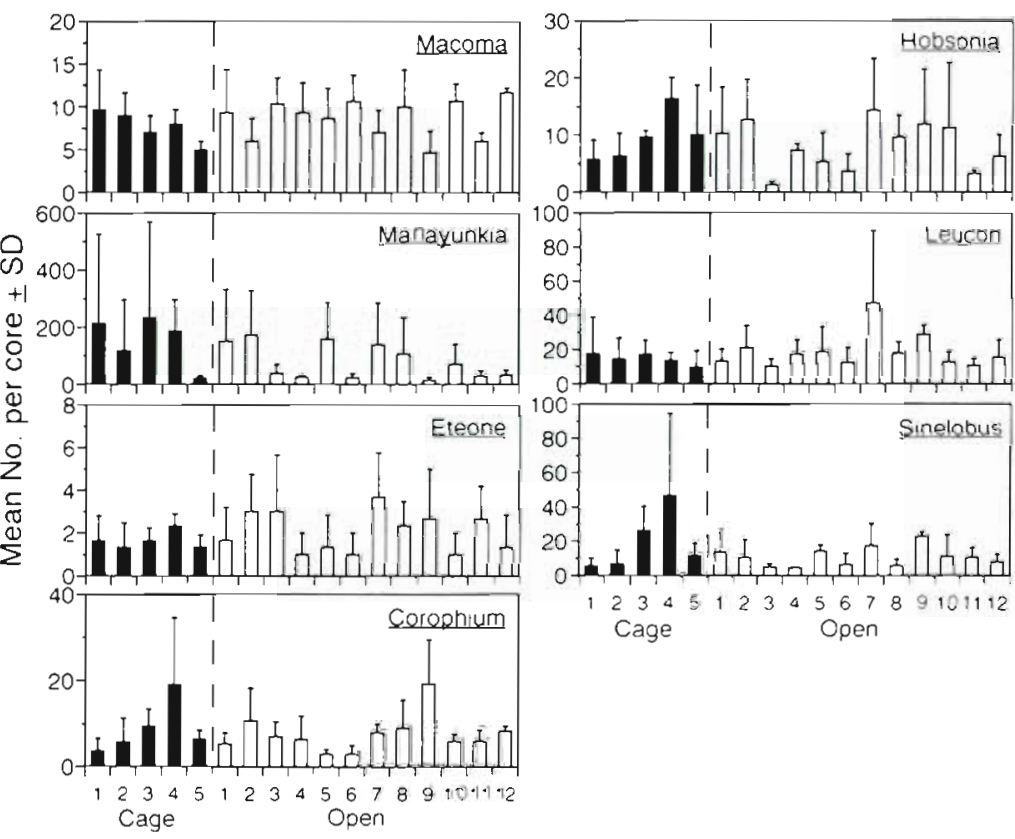

Fig. 7 Invertebrate numbers in Cages (C1. to C5, solid bars) and Open areas (O1 to 12, open bars) after the period of western sandpiper predation at Brunswick Point. Dashed line separates Cage and Open areas. Asterisk prior to species name denotes a significant Predation effect in the ANOVA (Table 5) tested showed similar mean numbers per core in Cage or Open areas (e.g. Macoma balthica, Mya arenaria, Hobsonia florida) or high variability in some Cage or Open areas (e.g. Manayunkia aestuarina, Leucon subnasica, Sinelobus stanfordi; Fig. 8).

\section{Before and After study}

Analyses of invertebrate numbers from random samples taken before and after the northward migration of western sandpiper showed few significant $B / A$ differences (Table 6 ). The bivalve $M a$ coma balthica showed significant $\mathrm{B} / \mathrm{A}$ differences at both Boundary Bay and Westham Island (Table 6, Figs. 9 \& 11). A decline in mean numbers of $M$. balthica was observed at Boundary Bay (Fig 9), where there was little evidence for western sandpiper predation (Table 4). In contrast, at Westham Island, with the highest index of predation (Table 4), the numbers of $M$. balthica increased in the period After predation (Fig 11).

Significant B/A differences were seen in the polychaete Manayunkia aestuarina, the cumacean Leucon subnasica, and the tanaid Sinelobus stanfordi at Brunswick Point (Table 6, Fig. 10). In these 
species there was a dramatic decline in numbers per core in the After samples (Fig. 10). However, these same species showed non-significant B/A effects at Westham Island, which was also used extensively for western sandpiper feeding (Table 6, Fig 11).

The Brunswick Point-Upper Roost site, which experienced intense use as a roost and feeding site during the period of study (author's pers, obs.), did not show significant B/A differences in any of the species tested (Table 6, Fig. 12). The trend was for a decline or similar numbers per core Before and After predation, with the exception of Manayunkia aestuarina for which mean numbers increased in the After samples (Fig. 12).

Evidence for spatial variability in invertebrate numbers was seen at all study sites (Table 6). At Brunswick Point and Westham Island, significant differences were seen at the scale of Sites (100 m apart). However, it was the scale of Plots (10s of metres apart) that was significant in 13 out of 23 cases tested (Table 6)
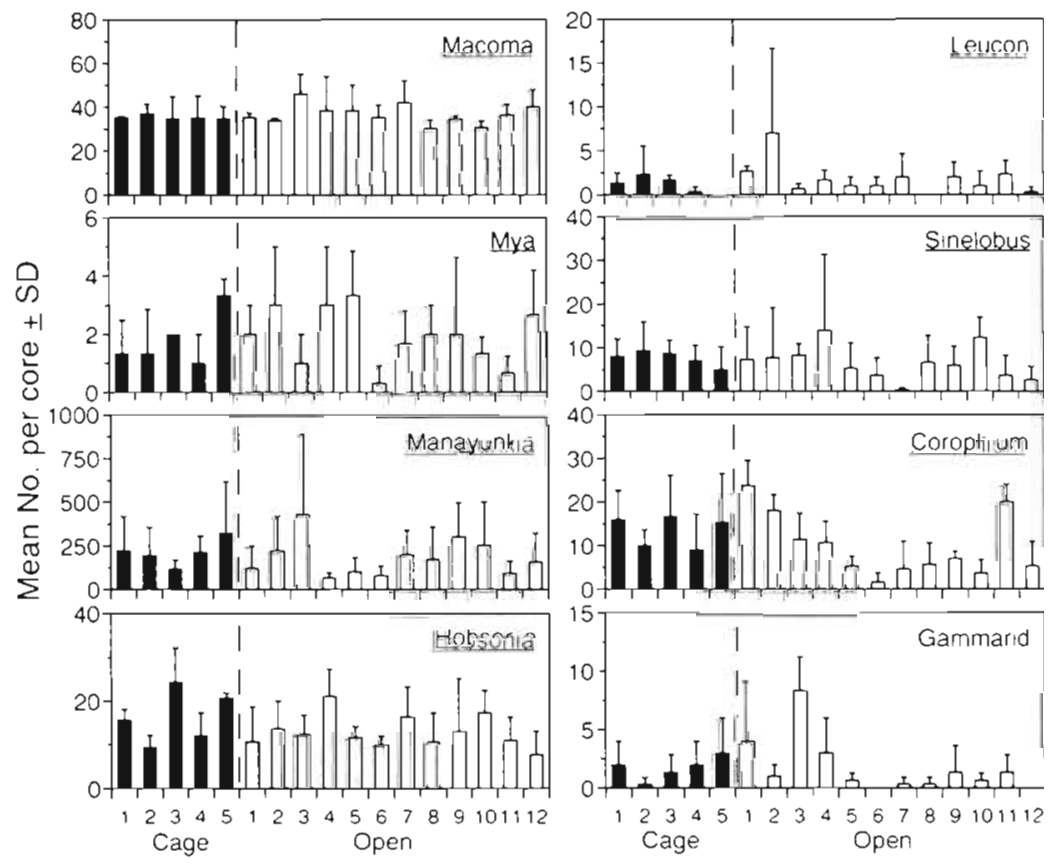

Fig. 8. Invertebrate numbers in Cages ( $\mathrm{C} 1$ to $\mathrm{C} 5$, solid bars) and Open areas 101 to 12 , open bars) after the period of western sandpiper predation at Westham Island. Dashed line separates Cage and Open areas. Asterisk prior to species name denoles a significant Predation effect in the ANOVA (Table 5)

Table 6. Analyses of variance of the number of invertebrates per core $\left[\log _{10}(x+1)\right.$ transformed $]$ for species at the 3 study sites. Mixed model ANOVAs with factors: Before/After (B/A), samples from April and May 1994; Site; B/A $\times$ Site; Plot(Site); and B/A $\times$ Plot(Site). Degrees of freedom for $F: B / A=1,2$; Site $=2,6 ; B / A \times$ Site $=2,6 ;$ Plot (Site) $=6,36 ; B / A \times P l o t(S i t e)=6,36$. See model statement in 'Methods' Significant p-values are shown in bold. Gammarids includes all amphipods except Corophium spp.

\begin{tabular}{|c|c|c|c|c|c|c|c|c|c|c|c|}
\hline \multirow[t]{2}{*}{ Location } & \multirow[t]{2}{*}{ Species } & \multicolumn{2}{|c|}{$\mathrm{B} / \mathrm{A}$} & \multicolumn{2}{|c|}{ Site } & \multicolumn{2}{|c|}{$\mathrm{B} / \mathrm{A} \times$ Site } & \multicolumn{2}{|c|}{ Plot(Site) } & \multicolumn{2}{|c|}{$\mathrm{B} / \mathrm{A} \times \operatorname{Plot}($ Site $)$} \\
\hline & & $F$ & $\mathrm{p}$ & $F$ & $\mathrm{p}$ & $F$ & $\mathrm{p}$ & $F$ & $\mathrm{p}$ & $F$ & $\mathrm{p}$ \\
\hline \multirow[t]{5}{*}{ Boundary Bay } & Batillaria zonalis & 0.07 & 0.821 & 2.06 & 0.209 & 3.06 & 0.122 & 2.45 & 0.043 & 1.47 & 0.218 \\
\hline & Macoma balthica & 45.63 & 0.021 & 0.22 & 0.809 & 0.09 & 0.916 & 2.00 & 0.091 & 2.54 & 0.037 \\
\hline & Eteone spp. & 1.20 & 0.388 & 0.14 & 0.873 & 1.03 & 0.411 & 0.99 & 0.449 & 2.85 & 0.022 \\
\hline & Manayunkia aestuarina & 0.06 & 0.832 & 1.10 & 0.392 & 2.53 & 0.160 & 2.62 & 0.033 & 2.63 & 0.032 \\
\hline & Podocopid ostracod & 9.92 & 0.088 & 0.19 & 0.832 & 2.23 & 0.189 & 2.27 & 0.059 & 0.23 & 0.966 \\
\hline \multirow{6}{*}{ Brunswick Point } & Macoma balthica & 12.08 & 0.074 & 0.10 & 0.907 & 0.50 & 0.631 & 5.91 & 0.0002 & 2.26 & 0.059 \\
\hline & Manayunkia aestuarina & 27.67 & 0.034 & 5.88 & 0.039 & 1.89 & 0.231 & 2.54 & 0.038 & 0.65 & 0.691 \\
\hline & Hobsonia florida & 3.50 & 0.202 & 0.88 & 0.461 & 0.27 & 0.772 & 3.78 & 0.005 & 3.43 & 0.009 \\
\hline & Leucon subnasica & 22.46 & 0.042 & 0.42 & 0.675 & 1.34 & 0.331 & 4.99 & 0.0008 & 5.49 & 0.0004 \\
\hline & Sinelobus stanfordi & 21.94 & 0.043 & 1.86 & 0.236 & 2.24 & 0.188 & 1.98 & 0.094 & 1.11 & 0.376 \\
\hline & Corophium spp. & 4.16 & 0.178 & 9.64 & 0.013 & 2.08 & 0.206 & 2.75 & 0.027 & 5.74 & 0.0003 \\
\hline \multirow{7}{*}{ Westham Island } & Macoma balthica & 1184.17 & 0.0008 & 4.28 & 0.070 & 0.00 & 0.999 & 9.04 & 0.0001 & 4.16 & 0.003 \\
\hline & Mya arenaria & 1.41 & 0.357 & 2.07 & 0.207 & 2.69 & 0.147 & 1.09 & 0.388 & 0.76 & 0.604 \\
\hline & Manayunkia aestuarina & 8.41 & 0.101 & 46.96 & 0.0002 & 0.50 & 0.629 & 0.99 & 0.450 & 1.14 & 0.362 \\
\hline & Hobsonia florida & 0.00 & 0.988 & 11.42 & 0.009 & 0.12 & 0.893 & 9.51 & 0.0001 & 11.24 & 0.0001 \\
\hline & Leucon subnasica & 7.46 & 0.112 & 9.52 & 0.014 & 0.92 & 0.449 & 14.02 & 0.0001 & 3.71 & 0.006 \\
\hline & Sinelobus stanfordi & 0.03 & 0.887 & 6.08 & 0.036 & 0.49 & 0.636 & 5.19 & 0.0006 & 5.54 & 0.0004 \\
\hline & Corophium spp. & 1.52 & 0.343 & 1.14 & 0.382 & 7.87 & 0.021 & 4.96 & 0.0009 & 2.26 & 0.060 \\
\hline Brunswick Point & Macoma balthica & 1.47 & 0.349 & 7.05 & 0.027 & 0.55 & 0.604 & 1.20 & 0.327 & 3.65 & 0.006 \\
\hline \multirow[t]{4}{*}{ Upper Roost } & Manayunkia aestuarina & 12.29 & 0.072 & 3.97 & 0.080 & 0.35 & 0.715 & 1.58 & 0.182 & 0.79 & 0.582 \\
\hline & Hobsonia florida & 12.93 & 0.069 & 0.65 & 0.554 & 2.61 & 0.153 & 2.29 & 0.056 & 1.89 & 0.110 \\
\hline & Leucon subnasica & 0.47 & 0.564 & 3.46 & 0.100 & 1.09 & 0.393 & 3.64 & 0.006 & 1.64 & 0.164 \\
\hline & Sinelobus stanfordi & 9.15 & 0.094 & 16.64 & 0.004 & 1.44 & 0.308 & 0.69 & 0.661 & 1.17 & 0.343 \\
\hline
\end{tabular}



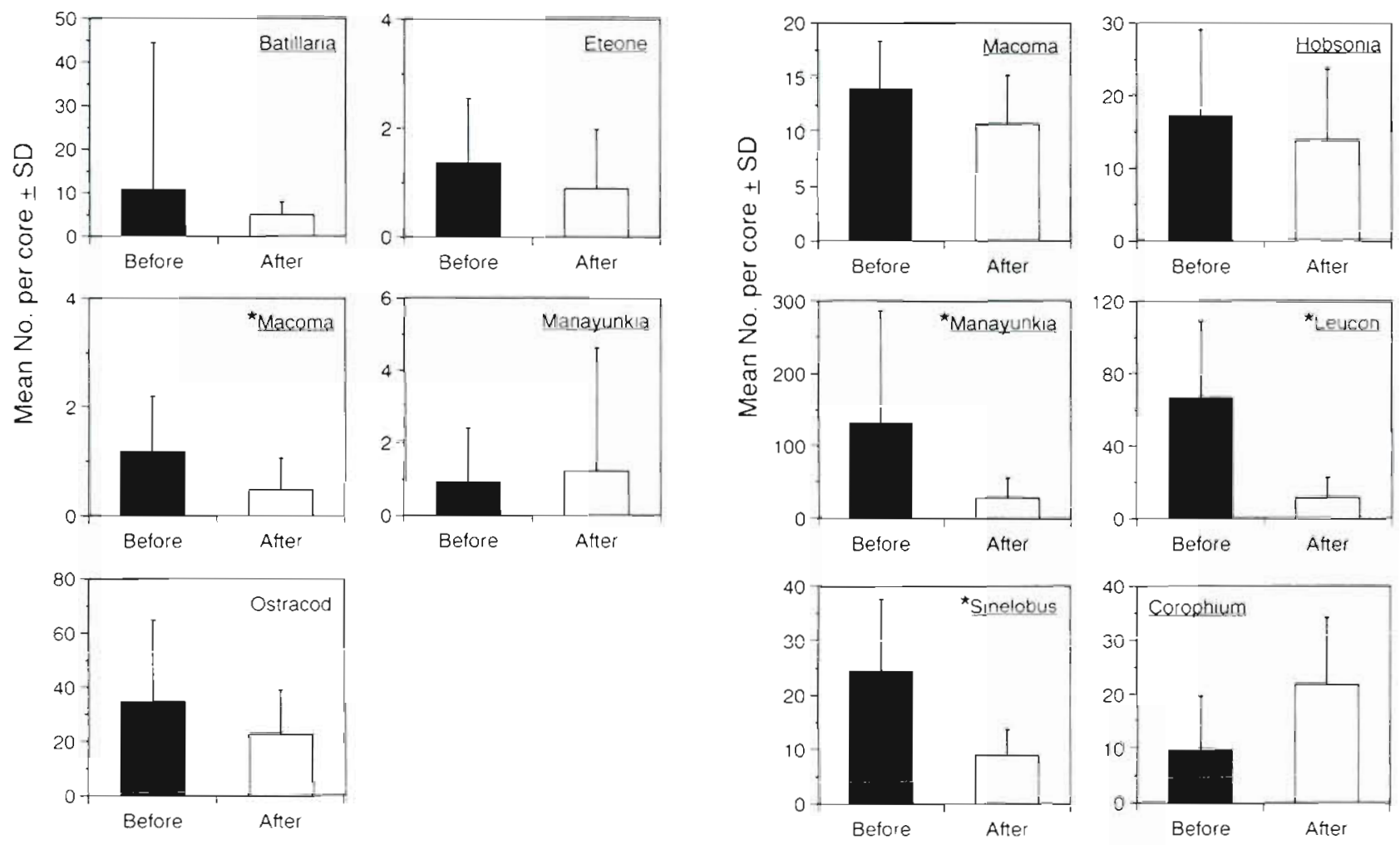

Fig. 9. Invertebrate numbers in Before/After sampling at Boundary Bay. Bars show the mean Before (solid bars) and After (open bars) the western sandpiper migration. Asterısk pnor to species name denotes a significant B/A effect in the ANOVA (Table 6)

Fig. 10. Invertebrate numbers in Before/After sampling at Brunswick Point. Bars show the mean Before (solid bars) and After (open bars) the western sandpiper migration. Asterisk prior to species name denotes a significant $B / A$ effect in the ANOVA (Table 6)

\section{DISCUSSION}

\section{Exclosure cage effects}

The presence of an exclosure cage in an area of soft sediments may have considerable influence by: altering the physical nature and hydrodynamics of the cage area (e.g. increased sediment removal or deposition); causing larval entrapment; providing substrate for fouling by animals or plants, which may further alter the cage environment; or providing refuges for large motile animals or the studied invertebrates themselves (Virnstein 1978, Peterson 1979, Hulberg \& Oliver 1980; see also discussion in Wilson 1991b, Olafsson et al 1994).

Two facets of these 'cage effects' need to be considered in an exclosure experiment: (1) changes in the sediment composition, and (2) changes in the invertebrate community beneath the exclosure cage. Consideration of hydrodynamic 'cage effects' on sediment composition have been made in previous shorebird exclosure experiments (Quammen 1981, 1984, Kent \& Day 1983, Raffaelli \& Milne 1987, Wilson 1989,

1994b). However, there are few studies that have considered the latter assumption that there is negligible prey movement during the experiment. (Hall et al. 1990b).

In the present study the physical effect of the exclosure cage on the sediment composition was considered by sampling sediments at the beginning and end of the experiment. While no difference was found in the percent of silt present in the cages between times, there was extensive scouring around the stakes at Westham Island as a result of high current flow. The observation of significant scouring without a change in sediment composition in the centre of the cage, also seen by Kent \& Day (1983), may be due to the lack of replication in the sediment sampling. As in other shorebird exclosure experiments, only a single core was taken within each cage (Quammen 1981, Kent \& Day 1983, but see Raffaelli \& Milne 1987, N = 3 cores), and there was no consideration of small-scale spatial variability in sediment composition.

Changes in the invertebrate community beneath the exclosure cage have been less well considered in shorebird exclosure experiments. While there is little 


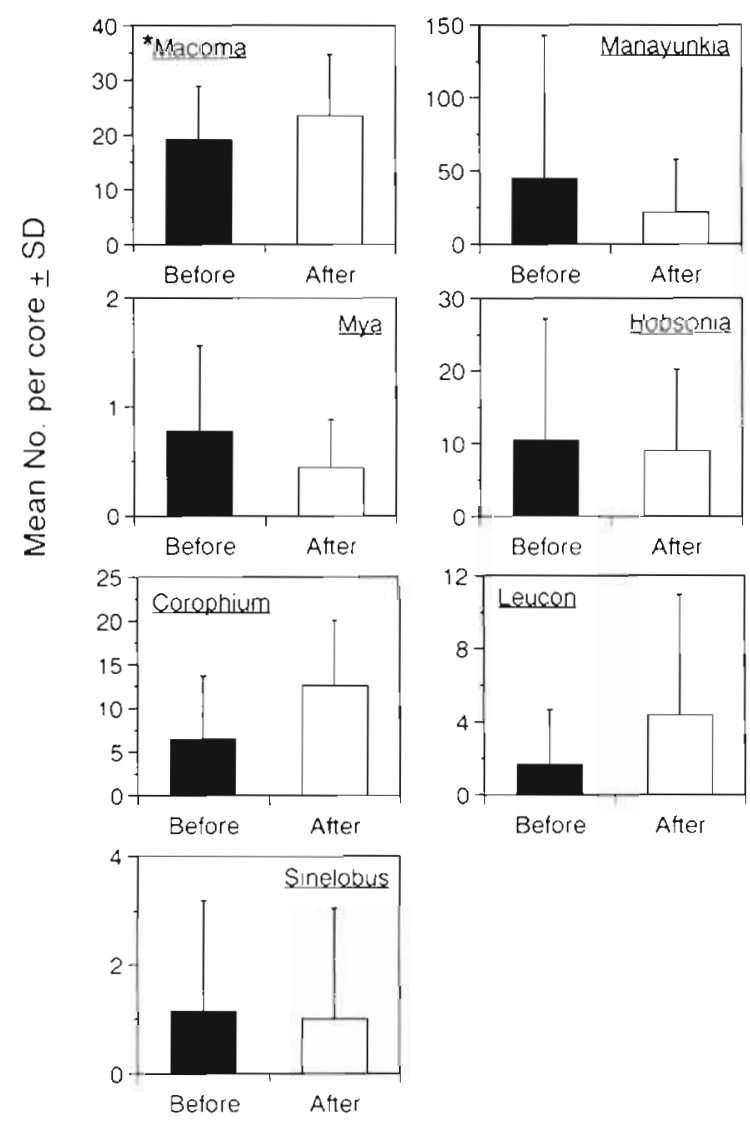

Fig. 11 Invertebrate numbers in Before/After sampling at Westham Island. Bars show the mean Before (solid bars) and After (open bars) the western sandpiper migration. Asterisk prior to species name denotes a significant B/A effect in the ANOVA (Table 6)

information on the distances moved by benthic animals, simulations by Hall et al. (1990b) have demonstrated that random prey movements can confound the results in caging experiments. The one shorebird exclosure experiment that directly examined prey movements found that there was not substantial migration of the polychaete Ceratonereis pseudoerythraeensis during the study (Kent \& Day 1983). However, prey mobility needs to be considered in exclosure experiments where the prey is highly mobile (e.g epifaunal species, or infaunal species with high potential for movement such as crustaceans; Hall et a]. 1990b).

A more simplistic approach, used in the present research, is to take an initial sample when the exclosure cage is constructed, and compare the invertebrate numbers at this time to those within the cage at the end of the experiment. This method, used by Wilson (1991a, $1994 \mathrm{~b}$ ), assumes that the cores taken at the corners of the exclosure cage are representative of invertebrate numbers inside the cage at the beginning of the exper-

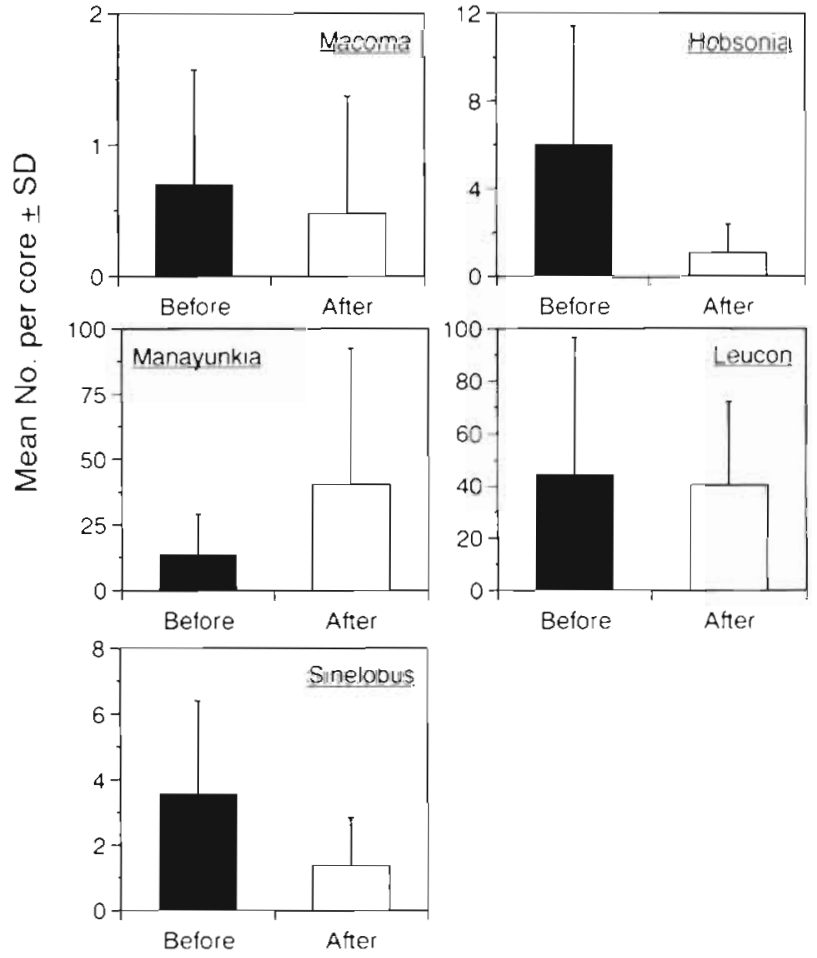

Fig. 12. Invertebrate numbers in Before/After sampling at Brunswick Point-Upper Roost. Bars show the mean Before (solid. bars) and After (open bars) the western sandpiper migration. Asterısk pror to species name denotes a significant B/A effect in the ANOVA (Table 6)

iment. In Wilson's exclosure experiments, changes in invertebrate numbers, irrespective of shorebird exclusion, were seen in the amphipod Corophium spinicorne (Wilson 1991a, 1994b) and the polychaetes Streblospio benedicti (Wilson 1991a) and Notomastus tenuis (Wilson $1994 \mathrm{~b}$ ). In C. spinicorne in 1 case there was a decline in numbers between the 2 sampling dates (Wilson 1991a). In the other there was an increase, which Wilson (1994b) suggested was due to immigration of $C$. spinicorne under the exclosure cages, an observation made for Corophium volutator in other shorebird exclosure experiments (Millard 1975 cited in Baird et al. 1985, Möller \& Rosenberg 1982, present study).

Significant differences in invertebrate numbers between cores taken immediately outside the exclosure cage in April (Before) and cores inside the exclosure cage in May (After) were seen in 9 of the 20 species tested (Table 3). Reduced numbers inside the exclosure cage in the After sampling were seen in 8 of these 9 mollusc, polychaete or crustacean species; the amphipod Corophium spp. increased in the exclosure cages. Differences could have resulted from 2 factors: (1) the movement of invertebrates into or out of the exclosure cage during the experiment, or (2) smallscale patchiness in invertebrate distributions, i.e. that 
cores taken immediately outside the exclosure cage were not good estimates of numbers inside. These factors need to be considered in shorebird exclosure experiments as they influence the Cage value in statistical comparisons to areas Open to predation. For example, the gastropod Batillaria zonalis, which is consumed by western sandpiper (Table 2), is associated with temporary pools of water that remain at low tide in Boundary Bay (Swinbanks \& Murray 1981, author's pers. obs.). Lower numbers of this species were found in the exclosure cages at the end of the experiment (Fig. 3) as a result of either migration from the exclosure cage or the association of $B$. zonalis with the surface pools. If, in contrast, invertebrate numbers had increased in the exclosure cage (e.g. Corophium spp. at Brunswick Point; Fig. 4) this could have produced a spurious predation effect in statistical analysis of the exclosure experiment.

Consideration of changes in invertebrate numbers within exclosure cages is particularly important in long-term exclosure experiments where there may be natural fluctuations in invertebrate prey irrespective of shorebird predation. Long-term studies have been more common at overwintering sites where the shorebird predator may be present for greater than 3 mo (Goss-Custard 1977, Kent \& Day 1983, Quammen 1984, Raffaelli \& Milne 1987, Kalejta 1993, Mercier \& McNeil 1994). The long time-scale of the exclosure experiment introduces 2 additional complexities to the experimental design: (1) the exclosure cage is maintained in the same location for the extended period of predation. Therefore, any cage effects on the sediment composition or infauna can accumulate over an extended time period. For example, there may be extensive fouling of the exclosure cage caused by algae or settled invertebrates, or the inclusion of nonfocus predators in the exclosure cage (e.g. crabs; Reise 1978). (2) Regular sampling is required throughout the experiment to determine the influence of invertebrate recruitment, mortality or species migrations, and other predators on invertebrate numbers, exclusive of the shorebird predator. For example, the exclosure cage may modify recruitment patterns in some invertebrates (Kent \& Day 1983, Wilson 1989). In these studies increased adult population density in the exclosure cage resulted in a decreased density of newly recruited polychaetes and amphipods respectively (Kent \& Day 1983, Wilson 1989). Consequently, there was more recruitment in areas open to shorebird predation with lower numbers of adults, counterbalancing the effect of shorebird predation on invertebrate densities. The importance of such adult-recruit interactions can only be assessed if the size structure of the invertebrate populations is also examined throughout the experiment.

\section{Effect of shorebird predation}

'The interpretation of experiments where no effects are apparent is problematic; the lack of effect may be real, or the experimental design may be inadequate for detecting the effect using inferential statistics.' (Hall et al. 1990 b, p. 657).

\section{Exclosure experiment}

The exclosure experiment conducted at 3 study sites on the Fraser River estuary did not detect a significant impact of western sandpiper on the densities of all infaunal marine invertebrate species. Even though shorebird numbers were an order of magnitude above most previous studies ie.g. at Brunswick Point the maximum daily estimate was 1.5 million western sandpiper on 4 May 1994; R. Butler unpubl data), and the predation occurred over a discrete period (19 April to 12 May), there was a significant predation effect in only 1 of the 20 species tested. Lower numbers of the polychaete Eteone spp. were seen in the Open area exposed to shorebird predation at Boundary Bay (Fig. 6), where there was little evidence for western sandpiper feeding.

The exclosure cages used in this experiment appeared to be adequate to test for an effect of predation by western sandpiper. The cages effectively excluded the target predator, did not change the sediment composition, were not excessively fouled, and were not present on the mudflat during periods of invertebrate recruitment. Consequently, comparing invertebrate numbers in the predator exclusion cage to areas exposed to shorebird predation should provide a valid test of the importance of western sandpiper predation to infaunal marine invertebrate populations

The general non-significance of these exclosure experiments is primarily due to the high variability seen in invertebrate numbers between the 5 Cages or 12 Open areas (Figs. 6 to 8). In this study, the spatial variability of invertebrate distributions was considered by including differences within and between the Cage or Open areas as an integral part of the nested analysis of variance. This is in contrast to other shorebird exclosure experiments where the authors acknowledge that there is spatial variability or patchiness in prey distributions (Kalejta 1993, Mercier \& McNeil 1994), but then reduce this variability by pooling the data prior to statistical analysis. Pooling occurs primarily because there are no replicate cores within the exclosure cage (Wilson 1989, 1991a, 1994b, Mercier \& McNeil 1994). Consequently, the exclosure cages are considered as 'replicates' in t-tests or 1-way ANOVAs that compare the Cage and Open areas (Wilson 1989, 1991a, 1994b, 
Kalejta 1993, Mercier \& McNeil 1994). The maximum distance apart of the cores used in calculating the Cage mean may, however, be large $(20 \mathrm{~m}$ : Wilson 1989, 1991a, 1994b; 60 m: Kalejta 1993; 650 m: Mercier \& McNeil 1994). In such studies, differences between exclosure cages and areas open to shorebird predation may simply reflect spatial variations in invertebrate abundance that are unrelated to the presence of a shorebird predator.

Consideration of the spatial scale of invertebrate distributions is critical in the design and statistical analyses of future shorebird exclosure experiments. While this study does not provide an exemplary shorebird exclosure experiment, the design tried to maximize the levels of replication ( 3 study areas, 5 cages, 12 open areas, 3 cores for each mean), within the time constraints posed by sorting invertebrate samples (total 198 cores). The fact that this experiment failed to detect declines in invertebrates in areas open to feeding is considered to be a valid test of the impact of western sandpiper predation on their marine invertebrate prey. The importance of a direct measure of shorebird predation in the Open areas is also emphasised by the potentially spurious decline in Eteone spp. at Boundary Bay, where there was little evidence for shorebird feeding

\section{Alternative approaches}

An alternative method to assess reductions in invertebrate numbers by shorebirds is to conduct sampling before and after a period of predation. Before and After sampling on the Fraser River estuary did not show consistent declines in invertebrate numbers at sites with a high index of shorebird predation (Westham Island, Brunswick Point) or evidence for high use during the last part of each tidal period (Brunswick Point-Upper Roost). Interpretation of the reduced numbers of some species at Brunswick Point after shorebird predation is complicated by the spatial variability shown in these same species at the scale of Sites $(100 \mathrm{~m}$ apart) or Plots (10s of metres apart; Table 6). With sampling only on 2 occasions (Before/After), it is impossible to differentiate between the 2 potential sources of decline: (1) that invertebrate numbers have declined as a direct effect of shorebird predation, or (2) that there are spatial and/or temporal differences in invertebrate numbers that occurred regardless of shorebird predation.

The Before/After study described here is effectively similar to an environmental impact study, with a 'natural' rather than a human impact. In this research, sampling was constrained to only 2 sampling dates because of the time required to collect and sort samples (total 216 cores). However, future research should consider using one of the many BACI (Before/After and Control/Impact) designs described in detail by Underwood (1991, 1992, 1993). This approach would avoid the shortcomings of exclosure experiments (e.g. cage effects, prey movements to or from exclosures), would consider spatial and/or temporal changes in invertebrate numbers, and would allow a rigorous statistical test of the impact of predation by shorebirds on their marine invertebrate prey.

\section{General considerations}

Baird et al. (1985, p. 576), in a review of shorebird predation, noted that the execution and interpretation of exclosure experiments to determine the impact of shorebird predators on benthic invertebrates need to be considered more carefully in the future'. Additionally, the conclusion of significant declines in invertebrate numbers due to shorebird predation in previous exclosure experiments (Schneider 1978, Schneider \& Harrington 1981, Kent \& Day 1983, Quammen 1984, Mercier \& McNeil 1994) should be reevaluated in light of potential flaws in their experimental designs or statistical analyses. Researchers designing exclosure experiments need to carefully consider the replication and interspersion of treatments and, most importantly, include the spatial scale of distribution of the invertebrate prey as a component of the experimental design.

A more general problem with detecting an impact of shorebird predation may be the implicit assumption that the scale at which a scientist samples soft sediments is the same as the impact of the shorebird predator. Sampling in soft sediments typically involves the collection of cores that sample a small discrete area (e.g. $5 \mathrm{~cm}, 10 \mathrm{~cm}$ ). In contrast, feeding by shorebirds such as western sandpiper is often in a more irregular fashion with periods of walking and pecking/probing on a larger spatial scale than the sample core. Thus, unless a flock of shorebirds passes through the area of study on a regular basis, reduction in invertebrate numbers may not be detectable using small diameter cores. The discordance in scales between impact and sampling might be one explanation for the lack of agreement between visual observations of high removal rates of invertebrates by shorebirds (e.g. Kalejta 1992) and the failure to detect significant declines in invertebrate numbers using sediment cores (e.g Kalejta 1993).

Additionally, because soft-bottom macrobenthos generally have clumped distributions (Thrush 1991), to show statistically significant reductions in density by predation there is a need for large sample sizes to reduce the variance about mean invertebrate densities (Baird et al. 1985). Restrictions on the number of sam- 
ples that can be collected and processed may, however, result in large standard deviations (e.g present study) and non-significant predation effects. A post hoc power analysis of the exclosure experiment used here shows that the smallest detectable difference ( $\delta$ at a power $1-\beta$ of 0.95 ) between Cage and Open areas, with the observed spatial variability $\left(\mathrm{s}^{2}\right)$, exceeds the value for the Cage mean in 11 out of 20 species (Table 7). The observed difference between Cage and Open means $(D)$ is positive (i.e. shows elevated densities in areas without predation) in 8 of the 15 species and for the total number of individuals per core at Brunswick Point and Westham Island, where there was evidence of significant shorebird predation (Table 7). In contrast, $D$ is negative (Open $>$ Cage) for all species except Eteonespp. (which showed a significant predation effect; Table 5) and for the total number of individuals per core at Boundary Bay (Table 7), where there was little evidence for shorebird predation around the exclosure cages.

Given the level of variation between sample cores, the current analysis detects 11.4 to $52.3 \%$ of the difference $(\delta)$ required to show a significant predation effect for individual species (Positive $D$, excluding the significant value of $100 \%$ for Eteone spp. at Boundary Bay;
Table 7). To highlight the problem of detecting significant reductions in invertebrate density, the value of $\delta$ for the total number of individuals per core is greater than the Cage mean at Boundary Bay, and 74 and $71 \%$ of the Cage mean at Brunswick Point and Westham Island respectively. This means that a significant predation effect will only be shown if the shorebirds are reducing the total number of invertebrates per core by $>70 \%$, a value which greatly exceeds estimates of consumption of shorebirds on the scale of large estuaries ( 6 to $44 \%$ of invertebrate production; Baird et al. 1985).

The conclusion reached from the power analysis is that, given the spatial variability of the invertebrate prey in the Fraser River estuary, it would be very difficult to show significant declines in invertebrate density by western sandpiper predation using the current exclosure design. In a comparable enclosure experiment in subtidal soft sediments, Hall et al. (1990a) concluded that: despite expectations of large rcductions in invertebrate densities by predators, the power to detect such effects may be limited because of high within-treatment variances; particularly in soft-bottom habitats where the results can also be confounded by physical and biological cage effects (Hall et al. 1990b).

Table 7. Estimates of smallest detectable difference $(\delta)$ between populations means using the present nested design. Calculation of $\delta$ from Zar (1984): $\delta=\sqrt{\left(2 \mathrm{ks}^{2} \phi^{2}\right) / \mathrm{n}}$ with $\mathrm{k}=2$ (Cage, Open), $\mathrm{s}^{2}=$ mean square Position(Predation-j+) from untransformed ANOVA, $n=21.18$ (harmonic mean of $n=12, n=36$ for Cage and Open areas respectively), and $\phi=29.6[1-\beta$ of 0.95$]$ with $v_{1}=1$, $v_{2}=15, \alpha=0.05$ (from Zar 1984, Appendix B, Fig. B.1.a). Actual difference $(D)$ ) Cage mean - Open mean. Value of $D$ as a percent of $\delta[1-\beta$ of 0.95$]$ calculated from the absolute value of $D$. Values in parentheses denote that the percentage difference is negative (i.e. Open > Cage)

\begin{tabular}{|c|c|c|c|c|c|c|c|}
\hline & & $\begin{array}{c}\text { Cage } \\
\text { mean } \\
(N=15)\end{array}$ & $\begin{array}{c}\text { Open } \\
\text { mean } \\
(\mathrm{N}=36)\end{array}$ & $s^{2}$ & $\begin{array}{c}\delta \\
{[1-\beta \text { of } 0.95]}\end{array}$ & $\begin{array}{l}\text { Actual } \\
\text { difference } \\
\text { (D) }\end{array}$ & $\begin{array}{c}\text { Das a } \% \text { of } \\
{[1-\beta \text { of } 0.95]}\end{array}$ \\
\hline Boundary Bay & $\begin{array}{l}\text { Batillana zonalis } \\
\text { Macoma balthica } \\
\text { Eteone spp. } \\
\text { Manayunkia aestuarina } \\
\text { Podocopid ostracod } \\
\text { Total individuals }\end{array}$ & $\begin{array}{r}2.53 \\
0.20 \\
2.80 \\
1.20 \\
7.20 \\
21.87\end{array}$ & $\begin{array}{r}3.11 \\
0.69 \\
1.50 \\
2.19 \\
13.11 \\
31.53\end{array}$ & $\begin{array}{c}9.02 \\
0.85 \\
1.2 \\
6.45 \\
561.42 \\
780.27\end{array}$ & $\begin{array}{r}3.55 \\
1.09 \\
1.30 \\
3.00 \\
28.01 \\
33.02\end{array}$ & $\begin{array}{r}-0.58 \\
-0.49 \\
1.30 \\
-0.99 \\
-5.91 \\
-9.66\end{array}$ & $\begin{array}{l}(16.3) \\
(45.0) \\
100 \\
(33.0) \\
(21.1) \\
(29.3)\end{array}$ \\
\hline Brunswick Point & $\begin{array}{l}\text { Macoma balthica } \\
\text { Manayunkia aestuanna } \\
\text { Eteone spp. } \\
\text { Hobsonia florida } \\
\text { Leucon subnasica } \\
\text { Sinelobus stanfordi } \\
\text { Corophium spp. } \\
\text { Total individuals }\end{array}$ & $\begin{array}{r}7.73 \\
154.00 \\
1.67 \\
9.60 \\
14.53 \\
19.33 \\
8.80 \\
230.80\end{array}$ & $\begin{array}{r}8.69 \\
79.92 \\
2.06 \\
8.14 \\
18.89 \\
10.86 \\
7.67 \\
145.81\end{array}$ & $\begin{array}{r}13.77 \\
14352.01 \\
2.80 \\
52.79 \\
244.17 \\
307.31 \\
70.16 \\
20712.49\end{array}$ & $\begin{array}{r}4.39 \\
141.62 \\
1.98 \\
8.59 \\
18.47 \\
20.72 \\
9.90 \\
170.14\end{array}$ & $\begin{array}{r}-0.96 \\
74.08 \\
-0.39 \\
1.46 \\
-4.36 \\
8.47 \\
1.13 \\
84.99\end{array}$ & $\begin{array}{c}(21.9) \\
52.3 \\
(19.7) \\
17.0 \\
(23.6) \\
40.9 \\
11.4 \\
50.0\end{array}$ \\
\hline Westham Island & $\begin{array}{l}\text { Macoma balthica } \\
\text { Mya arenaria } \\
\text { Manayunkia aestuarina } \\
\text { Hobsonia florida } \\
\text { Leucon subnasica } \\
\text { Sinelobus stanfordi } \\
\text { Corophium spp. } \\
\text { Gammarids } \\
\text { Total individuals }\end{array}$ & $\begin{array}{r}35.33 \\
1.80 \\
21.2 .87 \\
16.40 \\
1.13 \\
7.60 \\
13.40 \\
1.73 \\
294.40\end{array}$ & $\begin{array}{r}36.78 \\
1.92 \\
182.39 \\
12.94 \\
1.81 \\
6.50 \\
9.75 \\
1.75 \\
255.78\end{array}$ & $\begin{array}{r}45.35 \\
2.74 \\
29077 \\
59.97 \\
8.09 \\
35.51 \\
122.73 \\
13.45 \\
30869.94\end{array}$ & $\begin{array}{r}7.96 \\
1.96 \\
201.58 \\
9.15 \\
3.36 \\
7.04 \\
13.10 \\
4.34 \\
207.71\end{array}$ & $\begin{array}{r}-1.44 \\
-0.12 \\
30.48 \\
3.46 \\
-0.67 \\
1.10 \\
3.65 \\
-0.02 \\
38.62\end{array}$ & $\begin{array}{l}(18.1) \\
(6.1) \\
15.1 \\
37.8 \\
(19.9) \\
15.6 \\
27.9 \\
(0.5) \\
18.6\end{array}$ \\
\hline
\end{tabular}


Significant predation effects by shorebirds may, therefore, only be found in conditions where: (1) the study area has little environmental dynamics (sediment alteration) and is subject to intense feeding by shorebirds over a short time period (Piersma 1987); (2) the shorebird concentrates its feeding on a particular, abundant infaunal invertebrate [e.g. Corophium volutator: Wilson 1989; polychaetes: Kent \& Day 1983. Quammen 1984 (muddy sites only), Mercier \& McNeil 1994]; (3) the study area has high invertebrate densities so that massive declines can be detected (Székely \& Bamberger 1992; Table 7); and (4) the shorebird predator has a high energy demand during the period of study (e.g. during premigratory fattening or moult, at migratory stopovers, or at the end of long flights).

Finally, invertebrate density may not be the ideal measure for quantifying the effect of predation because of the variability inherent in benthic sampling (Grant 1981, Ens et al. 1994). Size-selective predation, as reported in shorebird studies by Wilson (1989), Raffaelli \& Milne (1987) and Kent \& Day (1983), or bioenergetic approaches may be more suitable in examining food-web interactions between shorebirds and their marine invertebrate prey.

Acknowledgements, 1 thank J. Black, R. Tikkemeijer, and S. Schneider for assistance with exclosure construction and sampling; $J$ Black for his assistance in the laboratory; $T$ Forbes for advice on sediment protocols; $V$. Bourne for access to the freeze drier; R. Butler and M. Lemon for help with the 'poop' surveys; J. M. Orensanz and E. Bousfield for invertebrate species identifications; W. H. Wilson for advice on exclosure cages; J. Smith, D. Morrisey, and R. Cole for statistical advice; K. Vermeer and R. W. Elner for unpublished data on western sandpiper diets; R. Butler, M. Lemon, B. Sandercock and K. $O$ 'Reilly for sharing their wisdom on western sandpiper; and R. W. Elner, D. Lank, R. Ydenberg, C. Hitchcock, and R. Butler for comments on the manuscript. The critical reviews of $A$. Metaxas, S. Hurlbert and the anonymous reviewers greatly clarified the final version. This research benefited from interactions with attendees of 2 western sandpiper workshops at Simon Fraser University, and visits from B. Ens and $T$ Piersma. Research support was provided from the Environment Canada Fraser River Action Plan through a Postdoctoral fellowship to the author from the Chair in Wildlife Ecology, Simon Fraser University.

\section{LITERATURE CITED}

Baird D, Evans PR, Milne H, Pienkowski MW (1985) Utilization by shorebirds of benthic invertebrate production in intertidal areas. Oceanogr Mar Biol Ann Rev 23:573-597

Botton ML (1984) Effects of laughing gull and shorebird predation on the intertidal fauna at Cape May, New Jersey. Estuar Coast Shelf Sci 18:209-220

Butler RW (1994) Distribution and abundance of western sandpipers, dunlins, and black-bellied plovers in the Fraser River estuary. In: Butler RW, Vermeer K (eds) The abundance and distribution of estuarine birds in the Stralt of Georgia, British Columbia. Occasional Paper No. 83, Canadian Wildlife Service, Ottawa, p 18-23
Butler RW, Kaiser GW, Smith GEJ (1987) Migration chronology, length of stay, sex ratio, and weight of western sandpipers, (Calidris mauri) on the south coast of British Columbia. J Field Ornithol 58:103-111

Duffy DC, Atkins N, Schneider DC (1981) Do shorebirds compete on their wintering grounds? Auk 98:215-229

Eckman JE (1979) Small-scale patterns and processes in a soft-substratum, intertidal community. J Mar Res 37 $437-457$

Ens BJ, Plersma T, Drent RH (1994) The dependence of waders and waterfowl migrating along the East Atlantic Flyway on their coastal food supplies: what is the most profitable research programme? Ophelia (Suppl) 6 $127-151$

Coss-Custard JD (1977) The ecology of the Wash. IIl. Densityrelated behaviour and the possible effects of a loss of feeding grounds on wading birds (Charadrii). J Appl Ecol 14:721-739

Grant J (1981) A bioenergetic model of shorebird predation on infaunal amphipods. Oikos 37:53-62

Hall SJ, Raffaelli D, Robertson MR, Basford DJ (1990a) The role of the predatory crab, Liocarcinus depurator, in a marine food web. J Anim Ecol 59:421-438

Hall SJ, Raffaelli D, Turrell WR (1990b) Predator-caging experiments in marine systems: a reexamination of their value. Am Nat 136:657-672

Holme NA, McIntyre AD (1984) Sediment analysis. In: Holme NA, Mclntyre AD (eds) Methods for the study of marine benthos, 2nd edn. Blackwell Scientific Publications, Oxford, p 41-65

Hulberg LW, Oliver JS (1980) Caging manipulations in marne soft-bottom communities: importance of animal interactions or sedimentary habitat modifications. Can J Fish Aquat Sci 37:1130-1139

Hurlbert SH (1984) Pseudoreplication and the design of ecological field experiments. Ecol Monogr 54:187-211

Hurlbert SH, Chang CCY (1983) Ornitholimnology: effects of grazing by the Andean flamingo (Phoenicoparrus andinus). Proc Nat Acad Scj USA 80:4766-4769

Iverson GC, Warnock S, Butler RW, Bishop MA, Warnock N (1996) Spring migration of the western sandpiper (Calidris mauri) along the Pacific Coast: a telemetry study. Condor 98:10-21

Kalejta B (1992) Time budgets and predatory impact of waders at the Berg River estuary, South Africa. Ardea $80: 327-342$

Kalejta B (1993) Intense predation cannot always be detected experimentally: a case study of shorebird predation on nereid polychaetes in South Africa. Neth J Sea Res 31: 385-393

Kalejta B, Hockey PAR (1991) Distribution, abundance and productivity of benthic invertebrates at the Berg River Estuary, South Africa. Estuar Coast Shelf Sci 33:175-191

Kent AC, Day RW (1983) Population dynamics of an infaunal polychaete: the effects of predators and an adult-recruit interaction. J Exp Mar Biol Ecol 73:185-203

Mercier F, McNeil R (1994) Seasonal variations in intertidal density of invertebrate prey in a tropical lagoon and effects of shorebird predation. Can J Zool 72:1755-1763

Möller P, Rosenberg R (1982) Production and abundance of the amphipod Corophium volutator on the west coast of Sweden. Neth J Sea Res 16:127-140

Ólafsson EB, Peterson CP, Ambrose WG Jr (1994) Does recruitment limitation structure populations and communities of macro-invertebrates in marine soft sediments the relative significance of pre- and post-settlement processes. Oceanogr Mar Biol Ann Rev 32:65-109 
O'Reilly KM, Wingfield JC (1995) Spring and autumn migration in Arctic shorebirds: same distance, different strategies. Am Zool 35:222-233

Peterson CH (1979) Predation, competitive exclusion, and diversity in the soft-sediment benthic communities of estuaries and lagoons. In: Livingston RJ (ed) Ecological processes in coastal and marine systems. Plenum Press, New York, p 223-264

Piersma T (1987) Production by intertidal benthic animals and limits to their predation by shorebirds: a heuristic model. Mar Ecol Prog Ser 38:187-196

Quammen ML (1981) Use of exclosures in studies of predation by shorebirds on intertidal mudflats. Auk 98:812-817

Quammen ML (1984) Predation by shorebirds, fish, and crabs on invertebrates in intertidal mudflats: an experimental test. Ecology 65:529-537

Raffaelli D, Milne $H$ (1987) An experimental investigation of the effects of shorebird and flatfish predation on estuarine invertebrates. Estuar Coast Shelf Sci 24:1-13

Reise K (1978) Experiments on epibenthic predation in the Wadden Sea. Helgol Wiss Meeresunters 31:55-101

Schneider DC (1978) Equalisation of prey numbers by migratory shorebirds. Nature 271:353-354

Schnelder DC, Harrington BA (1981) Timing of shorebird migration in relation to prey depletion. Auk 98:801-811

Swinbanks DD, Murray JW (1981) Biosedimentological zonation of Boundary Bay tidal flats, Fraser River Delta, British Columbia. Sedimentology 28:201-237

Székely T, Bamberger Z (1992) Predation of waders (Charadrii) on prey populations: an exclosure experiment J Anim Ecol 61:447-456

Thrush SF (1991) Spatial patterns in soft-bottom communities.

This article was submitted to the editor
Trends Ecol Evol 6:75-79

Underwood AJ (1991) Beyond BACI: experimental designs for detecting human environmental impacts on temporal variations in natural populations. Aust J Mar Freshwater Res 42:569-587

Underwood AJ (1992) Beyond BACI: the detection of environmental impacts on populations in the real, but variable, world. J Exp Mar Biol Ecol 161:145-178

Underwood AJ (1993) The mechanics of spatially replicated sampling programmes to detect environmental impacts in a variable world. Aust J Ecol 18:99-116

Virnstein RW (1978) Predator caging experiments in soft sediments: caution advised. In: Wiley ML (ed) Estuarine interactions. Academic Press, New York, p 262-273

Wilson WH Jr (1989) Predation and the mediation of intraspecific competition in an infaunal community in the Bay of Fundy. J Exp Mar Biol Ecol 132:221-245

Wilson $\mathrm{W}^{\prime} \mathrm{J} \mathrm{Jr}$ (1991a) The foraging ecology of migratory shorebirds in marine soft-sediment communities: the effects of episodic predation on prey populations. Am Zool $31: 840-848$

Wilson WH Jr (1991b) Competition and predation in marine soft-sediment communities Ann Rev Ecol Syst 21:221-241

Wilson WH (1994a) Western sandpıper (Calidris mauri). In Poole A, Gill F (eds) The birds of North America, No. 90. The Academy of Natural Sciences, Philadelphia; The American Ornithologists' Union, Washington, DC

Wilson WH Jr (1994b) The effects of episodic predation by migratory shorebirds in Grays Harbor, Washington. J Exp Mar Biol Ecol 177:15-25

Zar JH (1984) Biostatistical analysis, 2nd edn. Prentice-Hall, Englewood Cliffs, NJ

Manuscript first received: April 29, 1996

Revised version accepted: September 24, 1996 